\title{
Linking of antitumour trans NHC-Pt(II) complexes to G-quadruplex DNA ligand for telomeric targeting.
}

Jean-François Betzer ${ }^{\mathrm{a}}$, Frédérick Nuter ${ }^{\mathrm{a}}$, Mélanie Chtchigrovsky ${ }^{\mathrm{a}}$, Florian Hamon ${ }^{\mathrm{b}}$, Guillaume Kellermann ${ }^{\mathrm{c}}$, Samar Ali ${ }^{c}$, Marie-Ange Calméjane ${ }^{c}$, Sylvain Roque ${ }^{c}$, Joël Poupon ${ }^{\mathrm{d}}$, Thierry Cresteil ${ }^{\mathrm{a}}$, Marie-Paule TeuladeFichou $^{\mathrm{b}}$, Angela Marinetti ${ }^{\mathrm{a}}$, Sophie Bombard ${ }^{\mathrm{b}, \mathrm{c}}$.

${ }^{[a]}$ Institut de Chimie des Substances Naturelles, CNRS UPR2301, Université Paris-Sud, Université ParisSaclay, 1, av. de la Terrasse, 91198 Gif-sur-Yvette. ${ }^{[b]}$ CNRS UMR9187/INSERM U1196, Institut Curie, Centre Universitaire Paris XI, Bâtiments 110-112, 91405 Orsay, France, ${ }^{[c]}$ INSERM UMS S 1007, Université Paris Descartes, 45, rue des Saints Pères, 75270 Paris. ${ }^{[d]}$ Laboratoire de Toxicologie Biologique, Hôpital Lariboisière, 2 rue Ambroise Paré, 75475 Paris.

Abstract :

G-quadruplex structures (G4) are promising anticancerous targets. A great number of small molecules targeting these structures have already been identified through biophysical methods. In cellulo, some of them are able to target either telomeric DNA and/or some sequences involved in oncogene promotors, both resulting in cancer cell death. However, only a few of them are able to bind to these structures G4 irreversibly. Here we combine within the same molecule the G4-binding agent PDC (pyridodicarboxamide) with a $N$-heterocyclic carbene-platinum complex NHC-Pt already identified for its antitumour properties. The resulting conjugate platinum complex NHC-Pt-PDC stabilizes strongly G-quadruplex structures in vitro, with affinity slightly affected as compared to PDC. In addition we show that the new conjugate binds preferentially and irreversibly the quadruplex form of the human telomeric sequence with a profile in a way different from that of NHC-Pt thereby indicating that the platination reaction is oriented by stacking of the PDC moiety onto the G4-structure. In cellulo, NHC-Pt-PDC induces a significant loss of TRF2 from telomeres that is considerably more important than the effect of its two components alone PDC and NHC-Pt respectively.

\section{Introduction :}

The current arsenal of anticancer drugs used in chemotherapy is still largely based on compounds targeting genomic DNA. ${ }^{(1-3)}$ These agents act on proliferating cells by causing DNA damages that lead to inhibition of critical processes like replication and transcription and ultimately to blockage of cell proliferation ${ }^{(4)}$. Therefore, although the therapeutic window of DNA targeted drugs is narrow between anticancer activity and toxicity, these compounds, in combination with antibodies, constitute the first line treatment of most cancers. Hence, considerable efforts are still ongoing to find more effective DNA targeting drugs with fewer side effects. It is clear that this effort will be strongly supported by advances in molecular genetics and by the fast developing technology to analyze small molecule interactions genome-wide ${ }^{(5-7)}$.

At the molecular level, the main drawback of DNA binding drugs is their random distribution on the polymeric DNA scaffold thereby affecting genome functions in an uncontrolled manner. To minimize this phenomenon an approach currently explored is the targeting of secondary structures that can be found in strategic regions or genes as those involved in cell proliferation and genome stability. Ones such structures 
are DNA quadruplexes (G4-DNA) that are tetrahelicoidal elements locally formed by fold-over of guaninerepeat containing sequences ${ }^{(8-10)}$. G4 elements are well characterized in oncogenes and telomeric sequences and are known to act as roadblocks for DNA-processing proteins like polymerases and helicases, thereby acting as negative regulators of transcription and replication ${ }^{(11-13)}$. Quadruplexes can be specifically recognized by small molecules and thus represent targets to achieve regioselective pharmacological action directed at G-rich domains ${ }^{(14)}$. In this line, a large number of G4-ligands have been designed in the hope to turn-off oncogenes expression and to induce telomeric dysfunctions. The best examples of direct evidence for local action of G4 ligands concern, on one hand, the bisquinolinium derivative 360A (also called PDC: pyridodicarboxamide) that was shown to localize preferentially at telomeres ${ }^{(15)}{ }^{(16)}$ and, on the other hand, the bisquinoline Pyridostatin (PDS) that appeared to act at many oncogene loci including the Src oncogene (17). Indirect but robust data were also provided for the action of telomestatin and its derivatives at telomeres (18-20), and for specific effect of the bisquinolinium derivative PhenDC3 at minisatellites regions (21-23). Nonetheless, cellular phenotypes of G4 ligands are still rather diverse, which likely results from insufficient selectivity and cell line particularities. They feature however common characteristics which are induction of DNA damages at telomeres coupled with displacement of capping proteins ${ }^{(15,24-27)}$ and downregulation of oncogenes in particular c-myc (for reviews see ${ }^{(7,28,29)}$ ). Altogether G4 ligands show capacity to induce massive apoptosis in cancer cells with a low toxicity on normal cells. This selectivity is attributed to deficiencies in repair pathways of cancer cells that should result in higher persistence of G4 structures. Despite their remarkable cellular properties, it is not clear currently whether G4-ligands can be used alone as efficient anticancer drugs (see reviews $(14,30,31)$ ) with a few exceptions (see ${ }^{(32,33)}$ ). In counterpart combinations with other anticancer treatments are more promising and a number of G4 targeting compounds have shown synergistic activity with classical cytotoxic drugs ${ }^{(31,34)}$ and radiotherapy treatments, which has been validated in preclinical studies for some cases ${ }^{(35-37)}$.

Alternatively G4 ligands like PDS or PDC (Scheme 1) have been exploited to direct or redirect classical DNA alkylating agents (chlorambucil, or benzophenone) using conjugate scaffolds in which the active principle is linked to the G4 recognition moiety ${ }^{(38,39)}$. Following this strategy we recently launched a program for the development of such G4-targeted hybrid agents in which platinum complexes, that are well known for their capacity to coordinate to duplex and G-quadruplex DNA, ${ }^{(40-47)}$ will be the active principle. In addition, some of us have developed a new family of trans-configured square planar platinum ${ }^{\text {(II) }}$ complexes, typified by $1 \mathbf{a}$ in Scheme 1, which combine $N$-heterocyclic carbenes (NHC) and amines. These complexes display high cytotoxic activity against many cancerous cell lines ${ }^{(48,49)}$, while operating through a DNA-independent pathway differing from that of cisplatin and other platinum ${ }^{(\mathrm{II})}$ derived drugs used in the clinic (e.g. oxaliplatin) ${ }^{(50)}$. It was subsequently shown that these compounds and their bimetallic analogues are able to give adducts with duplex DNA in vitro coordinating specifically at guanine bases.

We speculated that by using a conjugate molecule comprised of a NHC-Pt moiety and of the G4-binding moiety PDC, we could redirect the activity of the NHC-Pt complexes at telomeres and in this way obtain a new agent for telomere-based anticancer therapy. Our studies in this field are reported hereafter. 


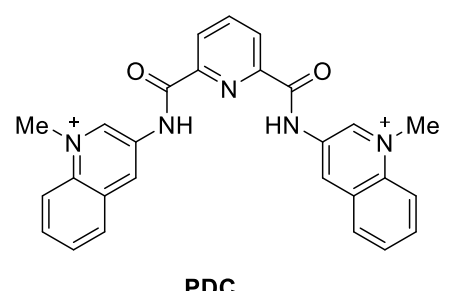

PDC

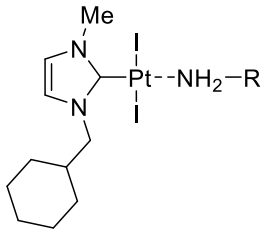

NHC-Pt-amine

1a, $\mathrm{R}=$ cyclohexyl

1b, $\mathrm{R}=n-\mathrm{C}_{4} \mathrm{H}_{9}$

Scheme 1: Chemical structure of PDC and representative trans-( $N$-heterocyclic carbene)(amine)-Pt ${ }^{(\mathrm{II})}$ complexes (1)

\section{Synthesis:}

For the synthesis of the conjugate scaffold, we have envisioned functionalizing the PDC unit with a primary amine group to graft it directly on the $\mathrm{Pt}^{(\mathrm{II})}$ cation as $\mathrm{RNH}_{2}$ ligand as shown in complexes $\mathbf{1}$. A number of PDC derivatives have been developed recently in the Teulade-Fichou's group, including derivatives with amino functions tethered to the central pyridine ring via $\mathrm{N}$-arylation of the corresponding chloro precursor. This is exemplified in scheme $2 \mathrm{a}$, using diaminobutane as linker that afforded compound $\mathbf{N H}_{\mathbf{2}}$-PDC ${ }^{(39)}$. This intermediate is fully suitable for grafting on the platinum ${ }^{(\mathrm{II})}$ cation, by using the ligand exchange methodology shown in scheme 2 b. Thus, the neutral $(\mathrm{NHC}) \mathrm{PtI}_{2}\left(\mathrm{H}_{2} \mathrm{~N}-\mathrm{PDC}\right)$ complex called NHC-Pt-PDC ${ }^{\mathbf{N}}$, could be prepared easily in two main steps: the first step is the synthesis of a $\left(\mathrm{NHC}^{2} \mathrm{Pt}^{(0)}(\mathrm{dvtms})\right.$ complex 3 (dvtms = divinyltetramethyldisiloxane), while the second step involves an oxidative addition of iodine and concomitant ligand exchange between the diene ligand of $\mathbf{3}$ and compound $\mathbf{N H}_{2}$-PDC.

The non-symmetrical imidazolium salt $\mathbf{2}$ was treated with potassium tert-butoxide to generate the corresponding $N$-heterocyclic carbene which was reacted in situ with a commercially available solution of platinum $^{(0)}$-1,3-divinyl-1,1,3,3-tetramethyldisiloxane complex (Karstedt catalyst). The NHC-Pt ${ }^{(0)}$ complex 3 was thus obtained by displacement of one of the dvtms units by the NHC ${ }^{(49,51,52)}$. Complex 3 was then oxidized by addition of iodine and the primary amine, $\mathbf{N H}_{\mathbf{2}}$-PDC, was added. The resulting mixed trans (NHC)PtI $2\left(\mathrm{H}_{2} \mathrm{~N}-\mathrm{PDC}\right)$ complex was obtained in $74 \%$ yield after purification by chromatography.

Finally, methylation of the quinoline units of NHC-Pt-PDC ${ }^{\mathbf{N}}$, to generate the active G4-binding quinolinium form, has been investigated. This methylation step proved more challenging than expected. Usually, transformation of bis-quinolines of these series into bis-quinoliniums requires harsh conditions, i.e. a very large excess of iodomethane and high temperature ${ }^{(53-55)}$. When these reaction conditions were applied to the neutral precursor, the desired methylated product called NHC-Pt-PDC, was not observed, probably due to side reactions between the platinum ${ }^{\text {(II) }}$ complex and the alkylating agent. Indeed, it is known that platinum ${ }^{\text {(II) }}$ derivatives can be converted into platinum ${ }^{(\mathrm{IV})}$ complexes by oxidative addition of iodomethane ${ }^{(56-58)}$. This side reaction could be prevented by using methyl triflate as alkylating agent instead of iodomethane. Thus addition of two equivalents of methyl triflate at $0{ }^{\circ} \mathrm{C}$ delivered the desired conjugate compound NHC-PtPDC in quantitative yield, by selective alkylation of the quinoline moieties. 
Then NHC-Pt-PDC has been evaluated for its DNA affinity. For comparison purposes, the previously known trans-(NHC)PtI 2 (cyclohexylamine) complex 1a, called NHC-Pt, as well as the analogous trans(NHC)PtI 2 (n-butylamine) complex $\mathbf{1 b}$ have been used as the references.

(a)<smiles>O=C(Nc1cnc2ccccc2c1)c1cc(Cl)cc(C(=O)Nc2cnc3ccccc3c2)n1</smiles>

(b)
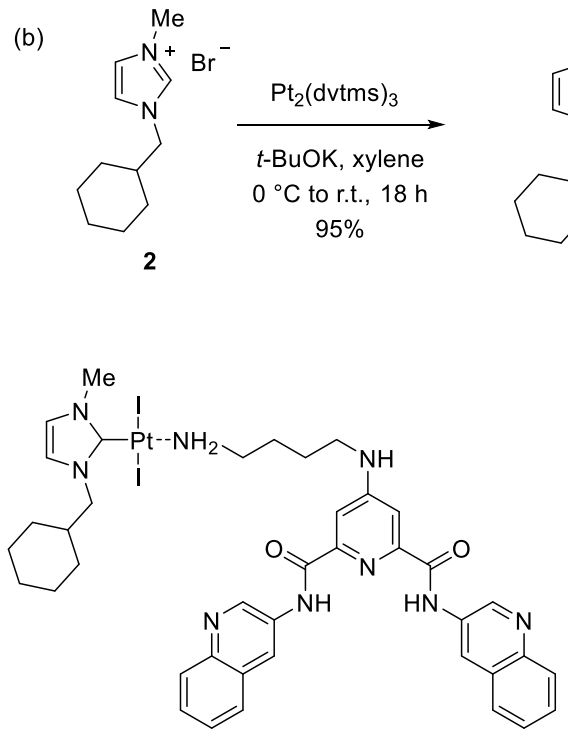

NHC-Pt-PDC ${ }^{N}$
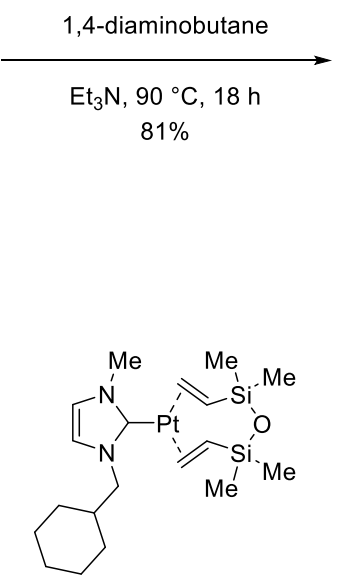

3
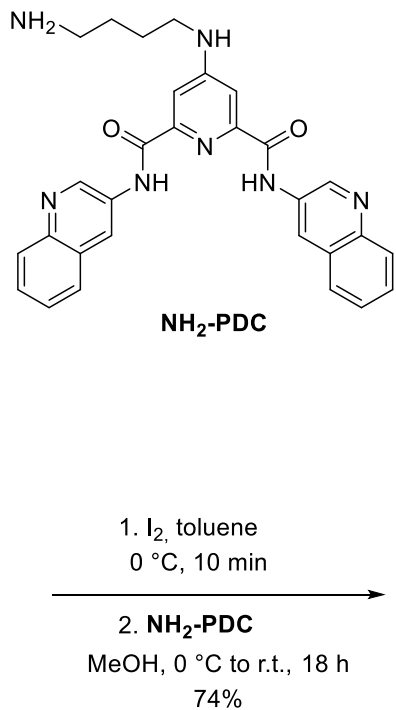

$74 \%$

Scheme 2: Synthesis of the conjugate NHC-Pt-PDC

\section{Interaction with Quadruplex DNA: Evaluation of Binding affinity}

NHC-Pt-PDC has been evaluated for its capacity to bind quadruplex structures using the G4-FID assay (FID=Fluorescence induced displacement assay) ${ }^{(59)}$. To this end a panel of four well-characterized quadruplex-forming sequences have been used corresponding to the human telomeric sequence $22 \mathrm{AG}$ $\left[\mathrm{AG}_{3}\left(\mathrm{~T}_{2} \mathrm{AG}_{3}\right)_{3}\right]$, the subtelomeric minisatellite sequence $25 \mathrm{CEB}\left[\mathrm{AG}_{3} \mathrm{TG}_{3} \mathrm{TGTA}_{2} \mathrm{GTGTG}_{3} \mathrm{TG}_{3} \mathrm{~T}\right]$, and the two oncogene promoter sequences c-kit2 $\left[\mathrm{G}_{3} \mathrm{CG}_{3}(\mathrm{CG})_{2} \mathrm{AG}_{3} \mathrm{AG}_{4}\right]$ and c-myc [TGAG $\mathrm{TG}_{3} \mathrm{TAG}_{3} \mathrm{TG}_{3} \mathrm{TA}_{2}$ ] respectively, as well as a 26bp duplex control sequence ds 26 [ $\left.\mathrm{CA}_{2} \mathrm{TCG}_{2} \mathrm{ATCGA}_{2} \mathrm{~T}_{2} \mathrm{CGATC}_{2} \mathrm{GAT}_{2} \mathrm{G}\right]$. The performances have been compared to those of the building blocks PDC and NHC-Pt. The displacement curves obtained for the various compounds are shown in Figure 1 and the $\mathrm{DC}_{50}$ values determined from the curves are listed in Table I. 

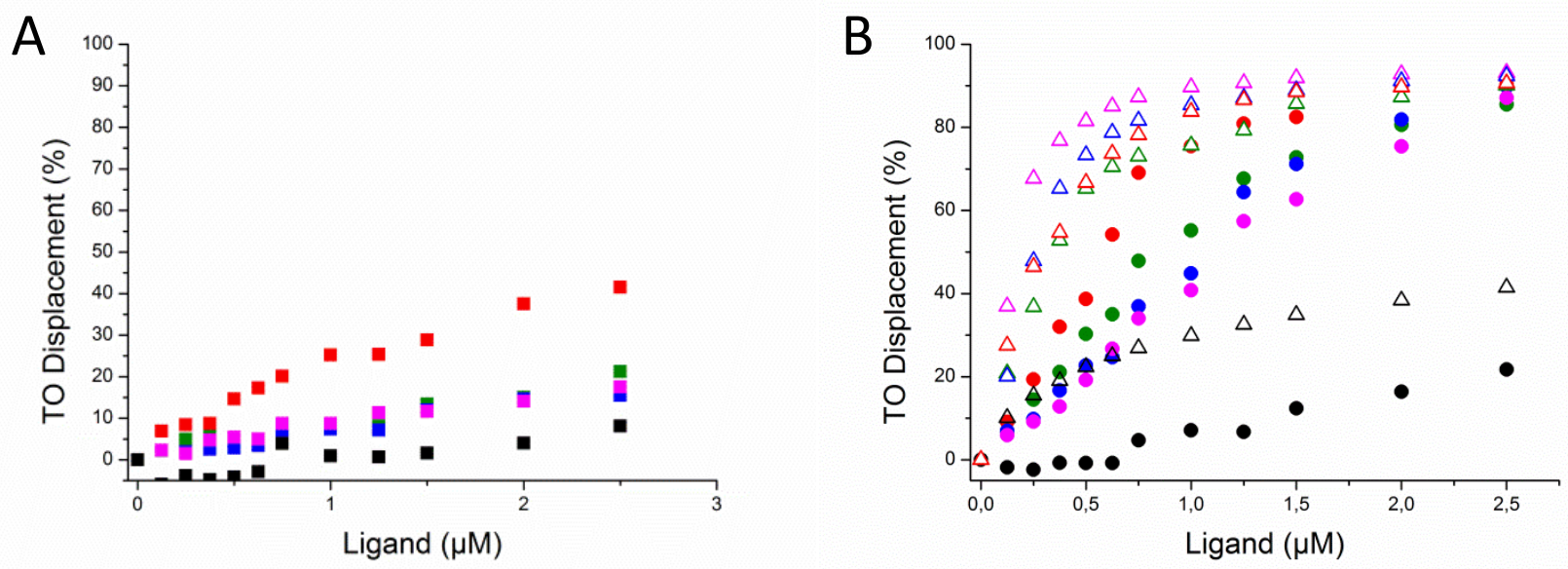

Figure 1: A) NHC-Pt induced TO displacement curves. Green: 22AG, red: c-kit2, blue: c-myc, pink: 25ceb and black squares: ds26 . B) TO displacement curves induced by conjugate NHC-Pt-PDC (circle) and PDC (triangle). Green: 22AG, red: c-kit2, blue: c-myc, pink: 25ceb and black: ds26.

We firstly observed that NHC-Pt binds very weakly to all the tested quadruplex and duplex structures (Figure 1A and Table1). In counterpart, the conjugate NHC-Pt-PDC binds two quadruplex oligonucleotides (22AG, c-kit2) with medium to high affinity $\left(\mathrm{DC}_{50}<1 \mu \mathrm{M}\right)$ and show a significantly weaker affinity $\left(\mathrm{DC}_{50} \geq\right.$ $1 \mu \mathrm{M}$ ) for the two others (c-myc, 25CEB). As c-myc, c-kit2 and CEB25 all exhibit parallel topology there is no clear topology preference appearing. However, the long loop present in CEB25 ${ }^{(60)}$ might disfavor the interaction as the highest $\mathrm{DC}_{50}(1.15 \mu \mathrm{M})$ is observed in this case. The comparison with PDC alone indicates that the affinity of the conjugate is decreased but to a reasonable extent considering that the $\mathrm{DC}_{50}$ value remains below $1 \mu \mathrm{M}$ at least in two cases (22AG and ckit2). The capacity to discriminate between various quadruplex forming sequences might result from enhanced steric hindrance of the conjugate as compared to PDC compound alone. Finally and importantly, displacement of the fluorescent probe TO from the duplex oligonucleotide ds26 is very weak, thereby indicating that NHC-Pt-PDC retained a high selectivity for quadruplex over duplex structure comparable to that of the model compound PDC.

Table 1: $\mathrm{DC}_{50}$ values $(\mu \mathrm{M})$ measured for the new conjugate and the references compounds with $4 \mathrm{G}$ quadruplex structures (22-AG, c-kit2, c-myc and 25CEB) and the control duplex ds26.

\begin{tabular}{|c|c|c|c|c|c|}
\hline Ligand & $22 \mathrm{AG}$ & c-kit2 & c-myc & 25CEB & ds26 \\
\hline NHC-Pt-PDC & 0.84 & 0.57 & 1.01 & 1.15 & $>2.5$ \\
\hline NHC-Pt & $>2.5$ & $>2.5$ & $>2.5$ & $>2.5$ & $>2.5$ \\
\hline PDC & 0.34 & 0.29 & 0.31 & 0.20 & $>2.5$ \\
\hline
\end{tabular}

Overall, linking the NHC-platinum moiety to the PDC core is affecting only moderately the binding affinity to the telomeric quadruplex DNA as already shown for other functionalized PDC derivatives ${ }^{(61)}$. Most importantly the high selectivity for quadruplex over duplex DNA is retained. Altogether these two features fully validate the molecular design proposed and suggest that NHC-Pt-PDC is potentially able to direct the platination reaction to telomeric quadruplexes. 


\section{In vitro platination of the G-quadruplex structure(s) formed by the telomeric sequence $22 \mathrm{AG}$}

The following step of the study was to determine if the conjugate was able to establish coordination interactions with the G4 structures formed by the telomeric sequence $22 \mathrm{AG}^{(62)}$. We have previously shown that such structures possess eight potential platination sites that are the four adenine residues (A1, A7, A13 and A19) of the loops and the four guanine residues belonging to the external G-quartet of the G4 structures (G2, G10, G14 and G22) ${ }^{(47)}$.

The platination sites (A and/or $\mathrm{G}$ ) depend on the nature of the ligand bound to the platinum atom ( $\mathrm{NH}_{3}$ or aromatic tridendate G4-binding motif) and also on the length of the linker connecting the platinum complex to the G4 binding motif ${ }^{(44,46)}$. On duplex DNA, guanines are known to be the major platination sites of cis- and trans-platinum $^{\text {(II) }}$ complexes that coordinate preferentially at the N7 position of the guanine ring ${ }^{(40)}$. Nonetheless, steric hindrance around the platinum atom can modulate the reactivity and accessibility of the coordination sites, as well as the stability of the resulting adduct ${ }^{(63)}$.

In the case of NHC-Pt, we previously observed that platination of duplex DNA strongly depends on the nature of the labile ligands bound to the platinum cation. Indeed, no DNA platination was observed when NHC-Pt was bearing two iodide ligands whereas the replacement of iodide by the more labile nitrate $\left(\mathrm{NO}_{3}\right)$ allowed the reaction of platination to occur ${ }^{(50)}$. These results clearly suggest that the nature of the ligands governs the aquation kinetic of NHC-Pt. Indeed, it is well established that the binding of cis- and transplatinum $^{(\mathrm{II})}$ complexes to DNA involves an aquation step consisting in the replacement of the initial labile ligands (usually iodide or chloride) by $\mathrm{H}_{2} \mathrm{O}$, the resulting mono- and bis-aqua complexes being more electrophilic, they represent the reactive species that binds to $\mathrm{DNA}^{(64-66)}$. The same behavior was observed in the case of quadruplex DNA (Figure 2A) thereby confirming that the lack of reactivity of NHC-Pt towards DNA is due to a very slow aquation reaction and is therefore independent of the substrate DNA conformation used.

Interestingly, NHC-Pt-PDC was able to platinate DNA in vitro without exchanging $\mathrm{I}^{-}$by $\mathrm{NO}_{3}{ }^{-}$ (Figure 2A). This remarkable difference between the two complexes suggests that the ligand exchange reaction on platinum is more efficient in the case of the conjugate scaffold. As the PDC moiety is unlikely to influence the reactivity of the metal towards water, it can be hypothesized that the confinement of the compound inside the DNA pocket, which establishes proximity between the metal and potential coordination sites (N7 or N1 of purines), is strongly favoring the whole process. In this regard direct coordination events (I-N exchange) cannot be excluded as it has already been shown with terpyridine platinum complexes ${ }^{(67)}$. Finally, the neutral precursor NHC-Pt-PDC ${ }^{\mathbf{N}}$ appeared unable to platinate quadruplex DNA (Figure 2A) in consistency with its absence of affinity for this DNA conformation. 

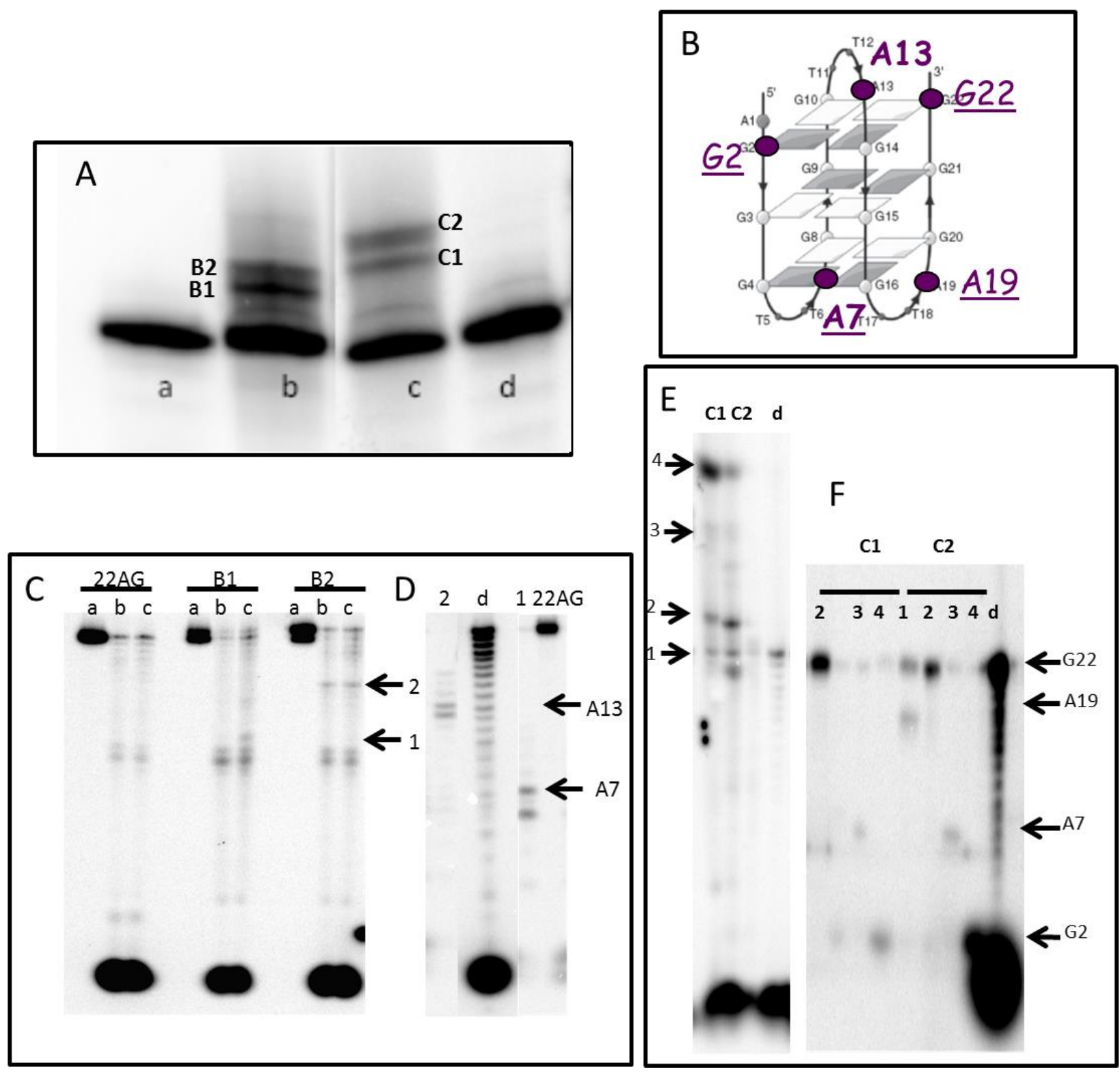

Figure 2: Platination sites of NHC-Pt and NHC-Pt-PDC on the anti-parallel G-quadruplex structure of the human telomeric sequence 22AG A) Denaturing gel electrophoresis of the platination reaction for the Gquadruplex in the absence of Pt complex (a), in the presence of NHC-Pt after I-/NO3- exchange (b), NHCPt-PDC (c), NHC-Pt-PDC ${ }^{\mathbf{N}}$ (d). B) Platination sites determined from exonuclease digestion of NHC-Pt in bold, of NHC-Pt-PDC in sub-lined. C) Denaturating gel electrophoresis of 3'-exonuclease digestion of platinated products of 22AG of bands B1 and B2 obtained by alkylation with NHC-Pt. D) Denaturating gel electrophoresis of the digested fragments treated by $\mathrm{NaCN}$ to eliminate the platinum adduct. E) Denaturating gel electrophoresis of 3'-exonuclease digestion of platinated products of $22 \mathrm{AG}$ of bands $\mathrm{C} 1$ and $\mathrm{C} 2$ obtained by alkylation with NHC-Pt-PDC; F) Denaturating gel electrophoresis of the digested fragments treated by $\mathrm{NaCN}$ to eliminate the platinum adduct. For C-F) The numbered pyrimidines correspond to the digestion arrests. Unit enzyme $/ \mu \mathrm{M}$ : lane a 0 ; lane $\mathrm{b}, 0.04$; lane c, 0.08 . Lane $\mathrm{d}$ is a partial digestion by 3 '-exonuclease digestion $(0,005$ units $)$ of $22 \mathrm{AG}$ that gives the reference scale for digested fragments.

Then the platination sites (Figure 2B) were identified by the classical protocol after isolation of the platination products from the gel (Figures $2 \mathrm{C}$ and $2 \mathrm{D}$ ). As shown on figure $2 \mathrm{~B}$ the control NHC-Pt platinates adenines A7 and A13. By contrast, the conjugate establishes metallic coordination with adenines A7 and A19 located above the 3'quartet, as well as with guanines G2 and G22 belonging to the 5' quartet. This platination profile clearly indicates that the PDC moiety governs significantly the platination sites. 
Altogether both the kinetics of ligand exchange and the platination profile are strikingly different between NHC-Pt, which does not bind quadruplex DNA, and the conjugate, which is a strong G4-binder. Therefore, the platination patterns seem to result only from chemical reactivity for the former whereas the confinement inside the G4 target is a strong determinant for the latter.

Subsequently, we checked the selectivity of platination of both platinum complexes towards the human telomeric G4 structure vs. duplex DNA. To this end, we used a system comprising both the G4 sequence (35G4) and a double stranded GXG sequence (13GXG) which enables to follow the platination of the two structures in a single experiment. This test has been previously validated as an in vitro intramolecular competition kinetic assay ${ }^{(68)}$. As seen from Figure 3, the ratio of the kinetic constants quadruplex/duplex is increased by a factor of seven for NHC-Pt-PDC as compared to NHC-Pt (Figures 3A-G). This result indicates that the G4-binding PDC motif induces preferential targeting of G4 structures and suggests that the platination reaction occurs after stacking of the ligand onto the G4-structure.

A

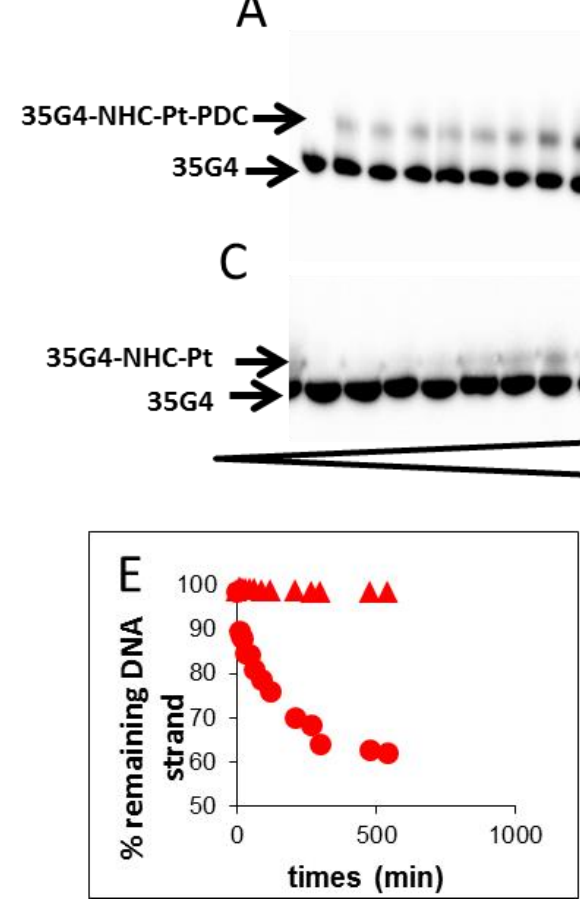

B

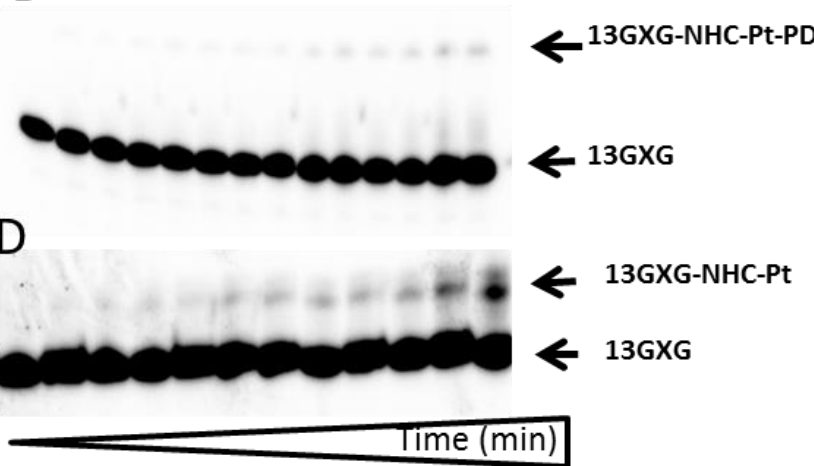

Time (min)

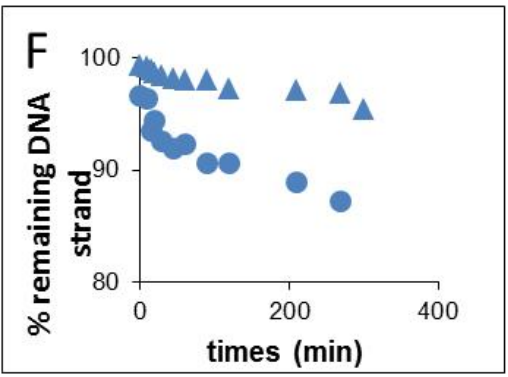

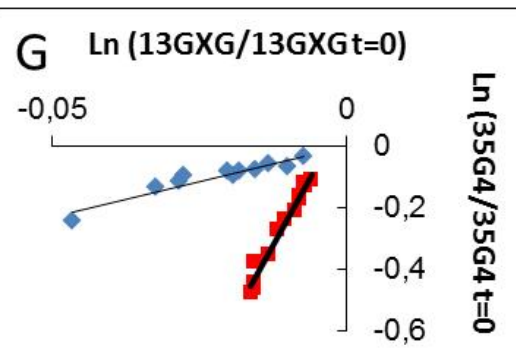

Figure 3. Denaturing gel electrophoresis of the kinetics of platination of 35G4/13GXG with either radiolabelled 35G4 (A,C) or radiolabelled 13GXG (B,D) by NHC-Pt-PDC (A, B) or NHC-Pt (C,D) . Typical experimental concentration curves for runs of the reaction between 35G4/13rGXG and NHC-PtPDC (E) or NHC-Pt (F) when either 35G4 (cercles) or 13GXG (triangles) was radiolabelled. Experimental determination of the ratio of the rate constants of quadruplex versus duplex platination (k35G4/k13GXG). Ln of the ratio of the remaining amount of $35 \mathrm{G} 4$ as function of the $1 n$ of the remaining amount of $13 \mathrm{GXG}$ at each time of the reaction for NHC-Pt-PDC (red squares) and NHC-Pt (blue diamonds)(G). The nomenclatures have been changed in figures A-D.

In conclusion linking of the PDC to NHC-Pt moiety has beneficial consequences in terms of faster ligand exchange on the metal thereby avoiding to perform halogen/nitrate ligand exchange to make the metal cation more reactive and of enhancement of selectivity of platination for the G-quadruplex conformation. 


\section{Antiproliferative properties of the conjugate NHC-Pt-PDC}

The two ovarian cancerous cell lines A2780 and A2780cis which are respectively sensitive and resistant to the anti-tumor drug cisplatin were chosen to detect if the new complexes overcome the resistance to cisplatin. Both cell lines have been treated for 96h with increasing doses of the conjugate NHC-Pt-PDC, its neutral precursor NHC-Pt-PDC ${ }^{\mathbf{N}}$ and the control compounds PDC and NHC-Pt (Figure 4A). We also used

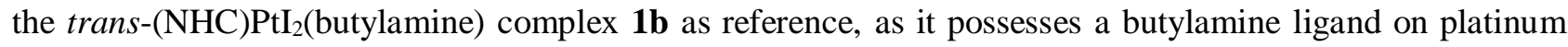
thereby representing the strict control of the conjugate. Complex $\mathbf{1 b}$ gave the same results as found previously for NHC-Pt ${ }^{(50)}$ showing no influence of the amine side chain on antiproliferative properties. Cellular proliferation decreases with increasing concentrations of the platinum complexes. NHC-Pt showed the highest cytotoxicity since its $\mathrm{IC}_{50}$ and $\mathrm{IC}_{80}$, for $\mathrm{A} 2780$ cis cell lines, are about 18 and 40 folds lower than that of NHC-Pt and NHC-Pt-PDC ${ }^{\mathbf{N}}$, respectively (Figure 4A and Table 2).

A2780
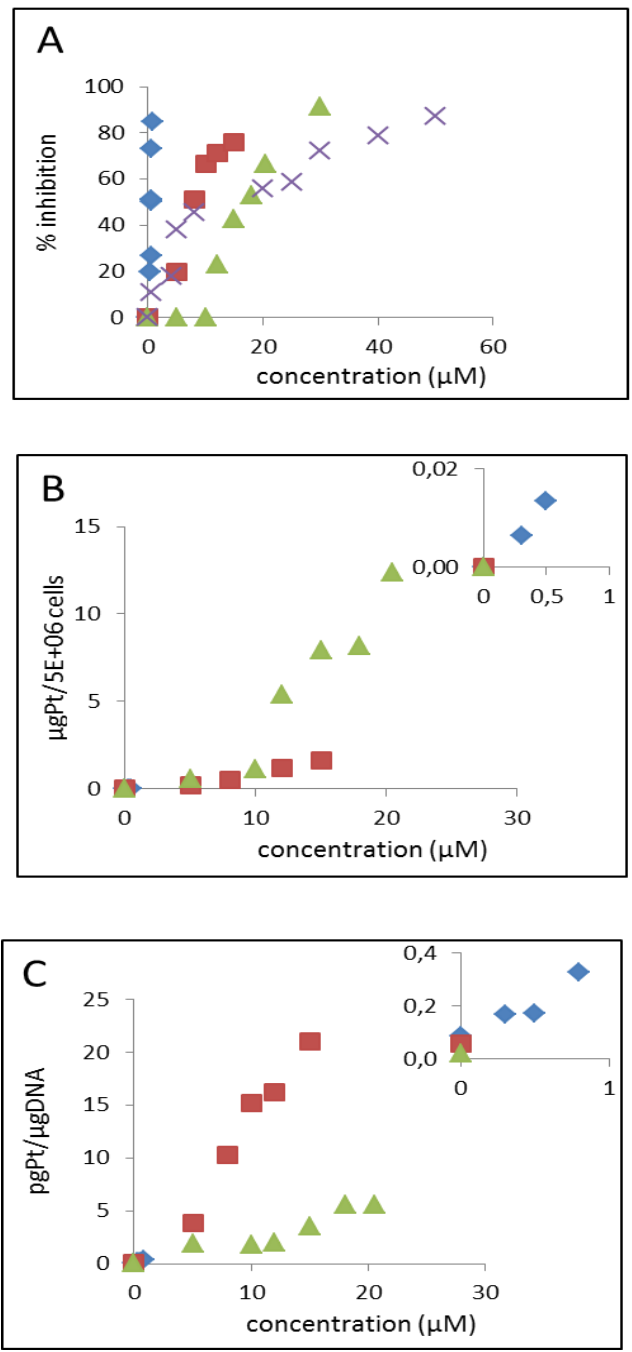

A2780cis
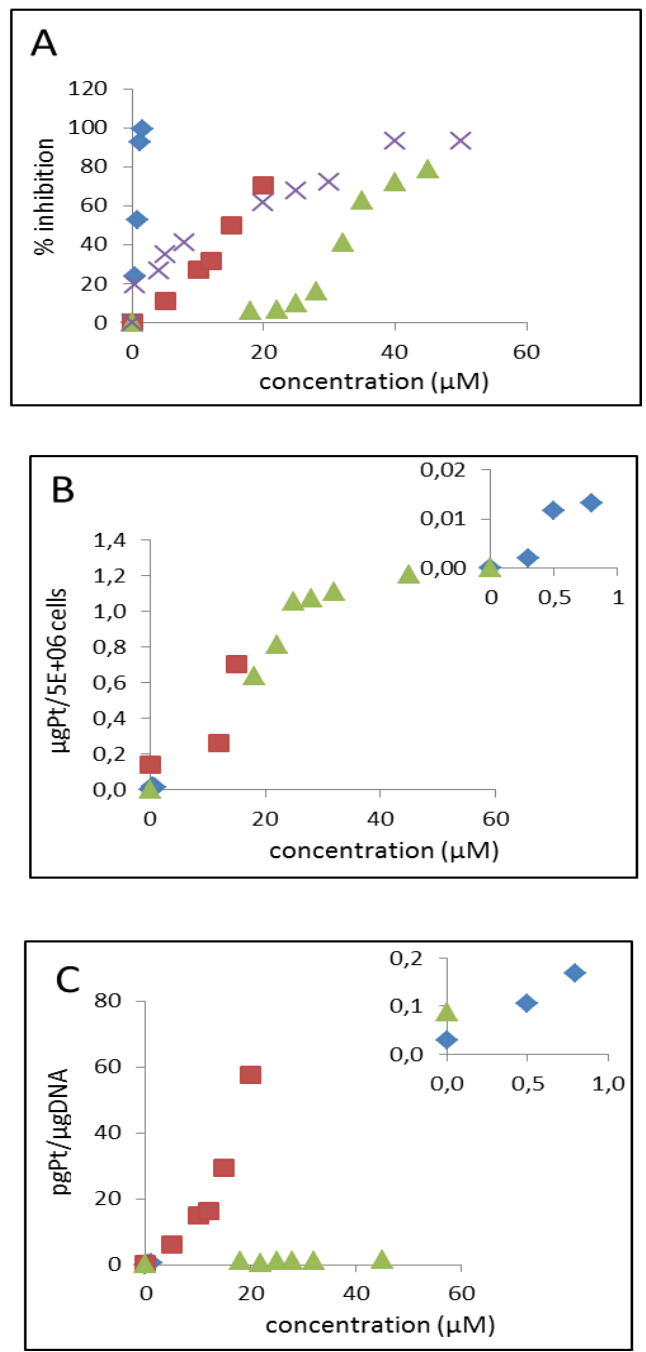

Figure 4: Antiproliferative activity of NHC-Pt-PDC (red squares), NHC-Pt-PDC ${ }^{\mathrm{N}}$ (green triangles), NHCPt (blue diamonds) and PDC (cross) in A2780 and A2780cis cells (A). Cellular uptake of platinum complexes for $5 \mathrm{E}^{+06}$ cells (B) and amount of platinum complexes bound / $\mu \mathrm{g}$ DNA (C) 
Table 2. Relative cellular uptake of platinum and platinum bound to DNA in A2780 and A2780cis cells, after treatment with NHC-Pt, NHC-Pt-PDC and NHC-Pt-PDC ${ }^{\mathbf{N}}$ (96h) at their respective $\mathrm{IC}_{50}$.

\begin{tabular}{|c|c|c|c|c|c|c|}
\hline & \multicolumn{3}{|c|}{ A2780 cells } & \multicolumn{3}{|c|}{ A2780cis cells } \\
\hline & NHC-Pt & $\begin{array}{c}\text { NHC-Pt } \\
\text { PDC }\end{array}$ & $\begin{array}{l}\text { NHC-Pt- } \\
\text { PDC }^{N}\end{array}$ & NHC-Pt & $\begin{array}{c}\text { NHC-Pt- } \\
\text { PDC }\end{array}$ & $\begin{array}{l}\text { NHC-Pt- } \\
\text { PDC }^{N}\end{array}$ \\
\hline $\mathrm{IC}_{50}$ conc. $(\mu \mathrm{M})$ & 0.5 & 8 & 18 & 0.8 & 15 & 33 \\
\hline Pt (complex) accumulation & 1 & 92 & 613 & 1 & 87 & 139 \\
\hline Pt (complex) bound to DNA & 1 & 48 & 32 & 1 & 55 & 6 \\
\hline
\end{tabular}

Of interest, the conjugate increases cellular proliferation inhibition in A2780 by a factor of about 2 with respect to PDC $\left(\mathrm{IC}_{50}\right.$ of $\left.15 \mu \mathrm{M}\right)$. Moreover, as previously shown for NHC-Pt, none of the platinum complexes, shows significant cross-resistance to cisplatin, since no significant differences between cisplatinsensitive and resistant cell lines could be noticed ( $\mathrm{IC}_{50}$ ratio A2780cis /A2780<2). Therefore, the association of PDC to NHC-Pt moiety in the same scaffold increases the efficiency of proliferation inhibition of PDC while it reduces that of NHC-Pt. In all cases, the neutral precursor NHC-Pt-PDC ${ }^{\mathbf{N}}$ remains the less toxic complex. Since Pt atom is easily detectable and quantifiable within cells and when bound to genomic DNA using ICP-MS, we used this physical property to quantify both the amount of platinum complexes accumulated in cells and bound to DNA following the treatments (Figures $4 \mathrm{~B}$ and $4 \mathrm{C}$ ). We choose to compare these amounts at the compound concentration inducing the same percentage of growth inhibition (i.e. 50\%, Table 2). In these conditions, the cellular uptake of NHC-Pt-PDC and its amount bound to DNA are increased by a factor of 92 and 48 respectively as compared to NHC-Pt. The same trend is observed for both cell lines and also for the neutral precursor NHC-Pt-PDC ${ }^{\mathbf{N}}$ whose cellular accumulation is dramatically enhanced likely due to its higher lipophilicity as compared to the two other compounds. Increased platinum accumulation (until a factor of 100) has already been seen for other trans-platinum complexes when compared to cisplatin and has been explained by the enhanced lipophilicity of the ligands ${ }^{(69,70)}$. Altogether, these data suggest that the cellular uptake of the NHC-Pt moiety is greatly improved when linked to PDC or PDC $^{\mathbf{N}}$. Concerning the binding to DNA, it is also clearly improved by the presence of the two cationic charges on the PDC moiety as expected. Of interest, the DNA adducts of NHC-Pt-PDC appear less toxic than those of NHC-Pt, since for the same growth inhibition, cells treated with NHC-Pt-PDC contain 48 times more platinum DNA adducts than cells treated with NHC-Pt. These results strongly suggest a globally more efficient DNA targeting but higher stability and/ or a less efficient removing of these adducts from DNA can also be involved. Indeed, it is known that mono-functional adducts of trans-platin can be removed through a chemical pathway by trans-labilizing nucleophilic agents $(70,71)$.

To check whether or not the binding of Pt complexes to DNA was capable to promote DNA cleavage, the fragmentation of DNA was evaluated by Terminal deoxynucleotidyltransferase dUTP Nick End Labelling (TUNEL) after a short exposure of A2780 cells to increasing concentrations of NHC-Pt-PDC and NHC-PtPDC $^{\mathbf{N}}$. Nicks generated into DNA by Pt complexes were filled with BrdU by TdT, allowing the estimation of cells with DNA damages. In untreated cells or in cells treated with DMSO only, the fraction of cells 
showing DNA damage accounted for less than 10\%. Both compounds strikingly elicited severe DNA damages in a dose-dependent manner and gave comparable amounts of DNA fragmentation in both cell lines (Figure 5). Therefore the binding of Pt-complexes to DNA does no perfectly match the generation of DNA fragments.

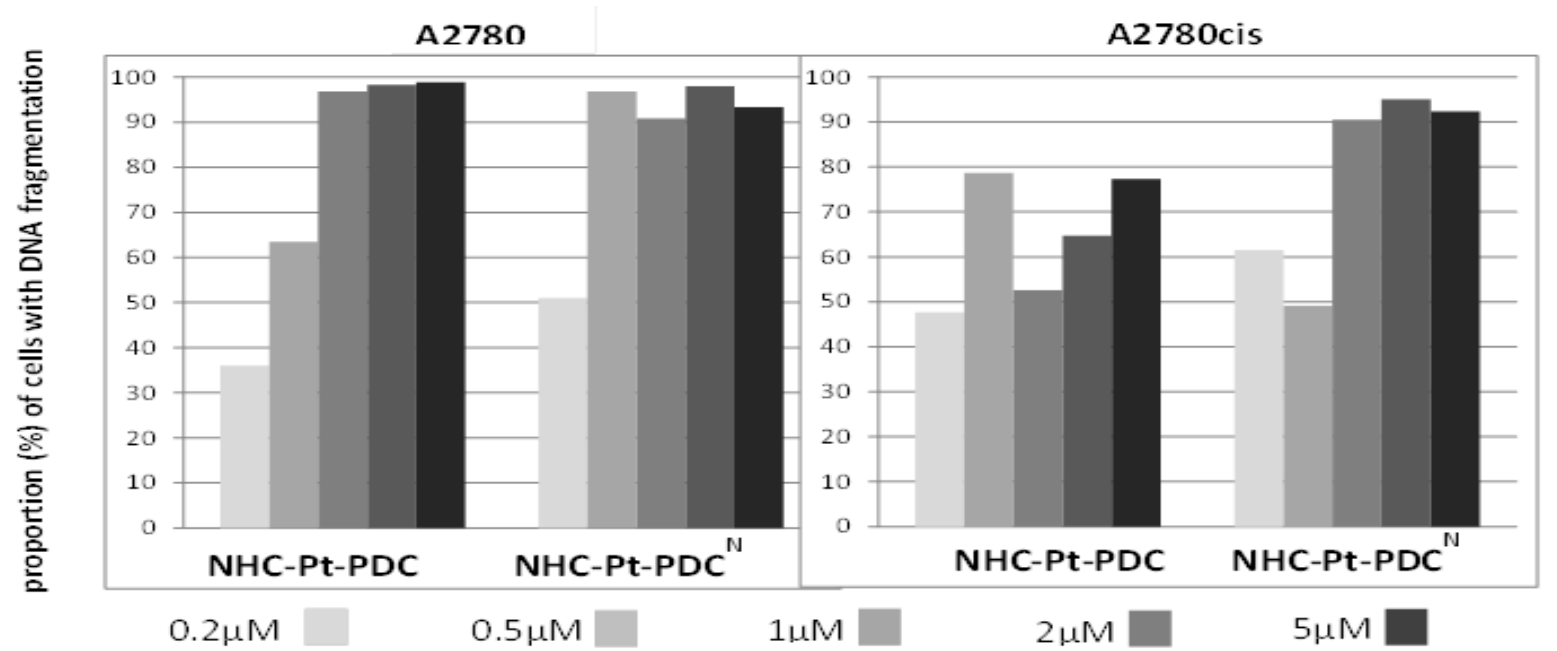

Figure 5 DNA fragmentation following exposure of A2780 and A2780cis cells to NHC-Pt-PDC complexes. Cells were treated for 24h. The incorporation of BrdU into DNA was detected with anti BrdU antibody and analysis was performed by FACS. Results are expressed as the percentage of cells with DNA fragmentation. The axis legend has been added

We then analysed the cell cycle progression of treated cells, using cisplatin as control (Figure 6).

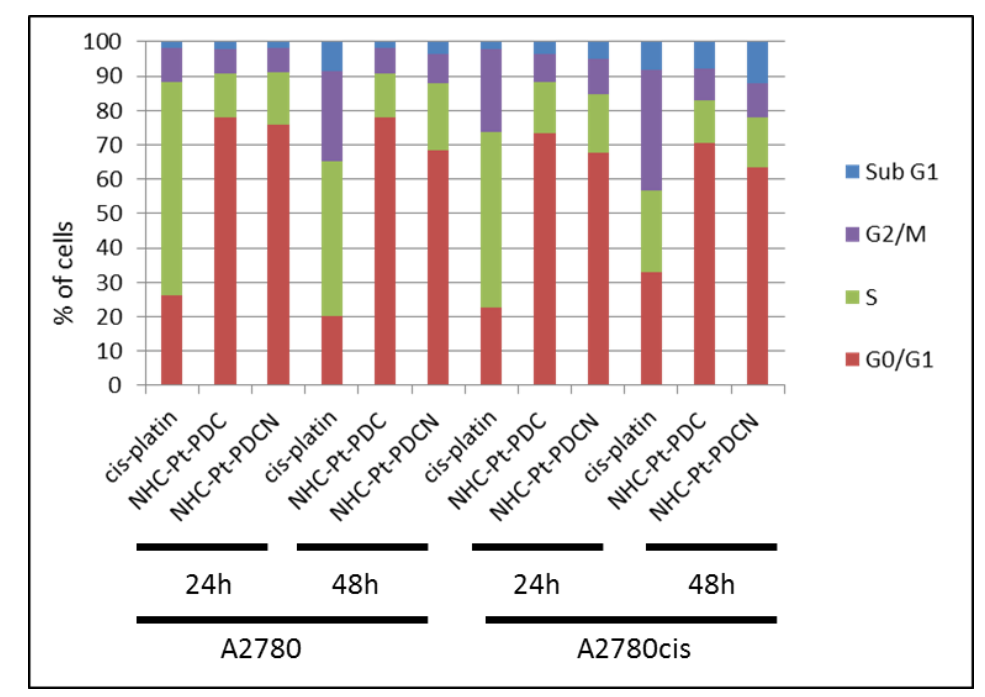

Figure 6: Cell cycle analysis of A2780 and A2780cis cells treated with 5 $\mu \mathrm{M}$ NHC-Pt-PDC and NHC-PtPDC $^{\mathrm{N}}$, in comparison with $5 \mu \mathrm{M}$ cis-platin for 24 and $48 \mathrm{~h}$. The percentages of cells in different phases of the cell cycle are expressed with respect to the total number of viable cells. The axis legend has been added

As expected, cisplatin causes a cell cycle arrest in S phase from 24 h overflowing on the G2/M phase at $48 \mathrm{~h}$. By contrast, for the conjugate and its neutral precursor, no noticeable cell cycle blocking effect was observed in S phase or G2/M as already found for NHC-Pt ${ }^{(50)}$. As well PDC alone does not modify cell cycle distribution as shown for many cell lines ${ }^{(24)}$. The lack of cell cycle arrest seems therefore a common 
feature of both PDC and NHC-Pt moieties. One can notice a very low apoptotic phase subG1 at 48 hours with the two lines, whereas NHC-Pt seems more prone to induce apoptosis ${ }^{(50)}$. This is in line with the comparable fragmentation of DNA estimated by TUNEL analysis elicited by Pt-complexes shortly after exposure. Therefore, both platinum conjugates did not modify the balance between cell phases and only induce a low entry in apoptosis after $96 \mathrm{~h}$ treatment.

To evaluate the participation of caspase-3 dependent pathways in the apoptotic process induced by NHC-PtPDC and NHC-Pt-PDC ${ }^{\mathrm{N}}$, the activation of caspase- 3 was assayed in cells treated for $24 \mathrm{~h}$ and $48 \mathrm{~h}$ with both compounds. Results were compared with caspase-3 activation elicited by doxorubin and cisplatin (Table 3). The reference compounds extensively activated caspase-3, whereas neither NHC-Pt-PDC nor NHC-Pt-PDC ${ }^{\mathrm{N}}$ modified the caspase activity.

Table 3 Caspases 3 activation experiments. A2780 and A2780cis cells were seeded in 96w microplates, treated for $24 \mathrm{~h}$ and $48 \mathrm{~h}$ with $1 \mu \mathrm{M}$ doxorubicin or $5 \mu \mathrm{M}$ cisplatin and complexes dissolved in DMSO or with vehicle only. Results are given as the fold-activation relative to the control (cells with DMSO alone). Results are the mean $\pm \mathrm{SE}$ for two experiments performed in duplicate.

\begin{tabular}{|l|c|c|c|c|}
\hline & & & & \\
DMSO & A2780 24h & A2780 48h & A2780cis 24h & A2780cis 48h \\
\cline { 2 - 5 } doxorubicin $1 \mu \mathrm{M}$ & 1 & 1 & 1 & 1 \\
cisplatin $5 \mu \mathrm{M}$ & $1.96 \pm 0.08$ & $15.50 \pm 2.21$ & $1.15 \pm 0.07$ & $14.09 \pm 1.08$ \\
NHC-Pt-PDC $5 \mu \mathrm{M}$ & $2.47 \pm 0.41$ & $11.91 \pm 0.08$ & $1.89 \pm 0.08$ & $9.99 \pm 0.79$ \\
NHC-Pt-PDC $^{\mathrm{N}} 5 \mu \mathrm{M}$ & $0.78 \pm 0.06$ & $0.82 \pm 0.00$ & $0.63 \pm 0.02$ & $0.61 \pm 0.01$ \\
& $1.13 \pm 0.01$ & $0.70 \pm 0.02$ & $1.01 \pm 0.18$ & $1.16 \pm 0.28$ \\
\hline
\end{tabular}

These data confirmed previous observations reporting a caspase- 3 independent activation of early apoptosis by NHC-Pt complexes ${ }^{(50)}$ thus suggesting that the NHC-Pt moiety might be responsible for the apoptosis cascade activation induced by the conjugate and its neutral counterpart.

\section{Preferential TRF2 delocalisation from telomeres by NHC-Pt-PDC}

PDC has been shown to bind preferentially to telomeres ${ }^{(15)}$ and to induce telomere aberrations that mainly consist of sister telomere fusions and also recombination preferentially involving the lagging strand telomeres ${ }^{(24,72)}$. This telomere instability is analogue to that of deprotected telomeres and could also come from delocalisation of proteins such as TRF2, a telomeric protein essential for the maintenance of telomeres ${ }^{(73)}$. This process has been already shown following cells treatments by other G-quadruplex ligands including telomestatin and RHPS4 ${ }^{(18,27,74)}$. Therefore, among the hallmarks of telomere integrity, we have chosen to quantify, in preliminary experiments, the amount of TRF2, bound to telomeres. We quantified the number of TRF2 foci, of A2780 and A2780cis cells treated with the four compounds, PDC, NHC-Pt, NHC-Pt-PDC ${ }^{\mathbf{N}}$ and NHC-Pt-PDC at doses that induce $75 \%$ cell growth inhibition. We found that PDC did not induce any decrease of the number of TRF2 foci, whereas NHC-Pt, NHC-Pt-PDC ${ }^{\mathbf{N}}$ and NHC-Pt-PDC induce a significant decrease of the number of TRF2 foci (30, 40 and 50\% respectively) (Figure 7). 


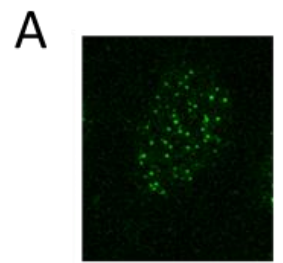

non-treated

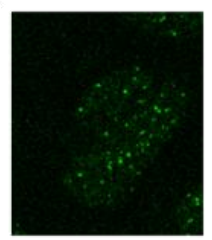

NHC-Pt-PDC ${ }^{N}$

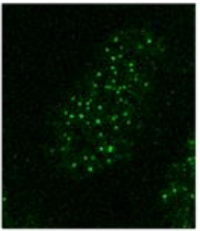

PDC

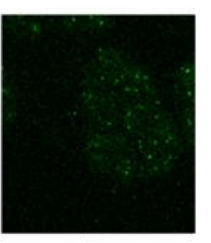

NHC-Pt-PDC

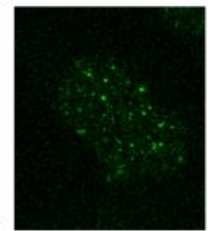

NHC-Pt

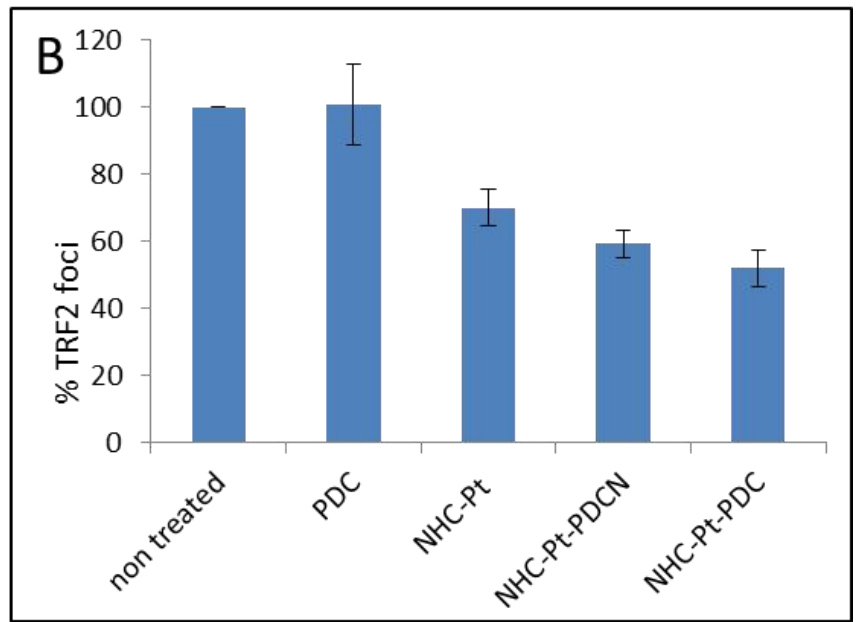

Figure 7: TRF2 delocalization from the telomere revealed by immunostaining with anti-TRF2 antibody in A2780 cells treated for 96h with of PDC, NHC-Pt, NHC-Pt-PDC $^{\mathbf{N}}$ and NHC-Pt-PDC at doses that induce $75 \%$ cell growth inhibition. (A) Cell imaging. Nuclei were counterstained with DAPI (blue). (B) \% of TFR2 foci per nucleus. Mean of at least two experiments

Since TRF2 foci are mainly localized at telomeres ${ }^{(75)}$, we assume that the decrease of TRF2 foci is correlated to TRF2 delocalisation from telomeres. Of interest, as for NHC-Pt, TRF2 delocalization from telomeres has already been observed upon cisplatin treatment by a mechanism that still remains to be elucidated. ${ }^{(76)}$. Our results indicate clearly that linking of NHC-Pt moiety to PDC improves TRF2 delocalization from telomeres, compared to NHC-Pt and PDC. Since TRF2 delocalization can induce telomere shortening, we analyzed telomere length of treated cells. None of the compounds induced a significant telomere shortening (Figure 8); the same absence of effect has been observed with telomestatin, a benchmark G4 binder ${ }^{(18)}$.

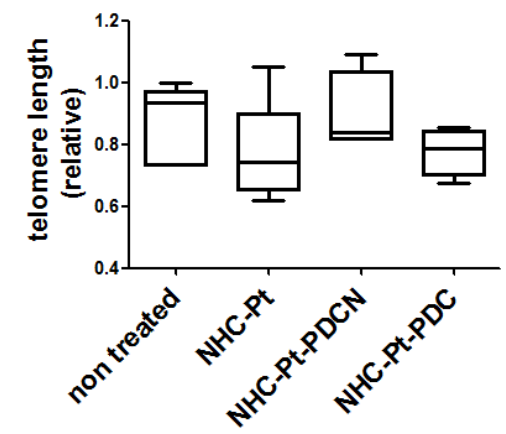

Figure 8: Relative telomere length of A2780 cells treated for 96h with NHC-Pt, NHC-Pt-PDC ${ }^{\mathbf{N}}$, and NHCPt-PDC at doses that induce $75 \%$ cell growth inhibition. It has been measured by qPCR. The values were normalized using $36 \mathrm{~B} 4 \mathrm{u}$ gene.

The delocalization of TRF2 from telomeres has also been described to upregulate the G-rich strand RNA transcribed from telomeric DNA, TERRA (77) (78), however we did not detect any increase of transcribed TERRA in our conditions (Figure 9). 


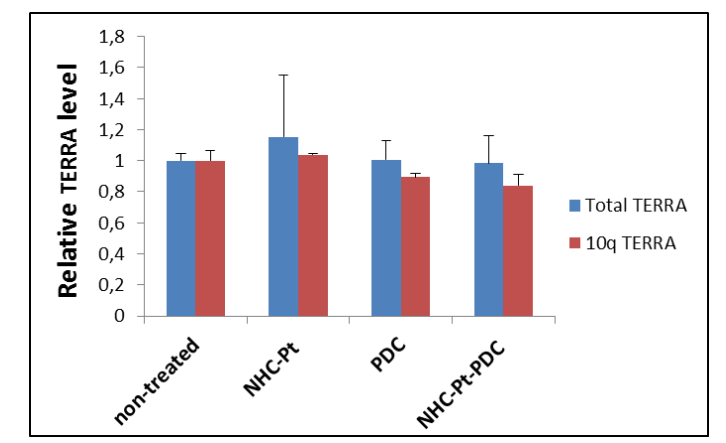

Figure 9: TERRA quantification. The level of total, as well as chromosome specific 10q TERRA were measured in A2780 cells by RT-PCR, after a culture of 96 hours with NHC-Pt, PDC and NHC-Pt-PDC at doses that induce $75 \%$ cell growth inhibition). The values were normalized using $\beta$-actin.

These results suggest that the partial displacement of TRF2 has not reached the critical level required to induce telomere shortening and TERRA transcription upregulation. Since many sequences from genomic DNA can form potential G-quadruplex structures ${ }^{(79,80)}$, that can be stabilised by G4-ligands which in turn may inhibit gene expression, mostly oncogenes ${ }^{(17,81,82)}$, we have also analysed the m-RNA level of three oncogenes (myc, Src and RhoC) previously described to be targeted by Pyridostatin (PDS) another benchmark G4 binder ${ }^{(17)}$. The transcription of these genes was not significantly affected upon treatment by the three platinum complexes (less than 2 fold) (Figure 10) indicating the absence of oncogene targeting.

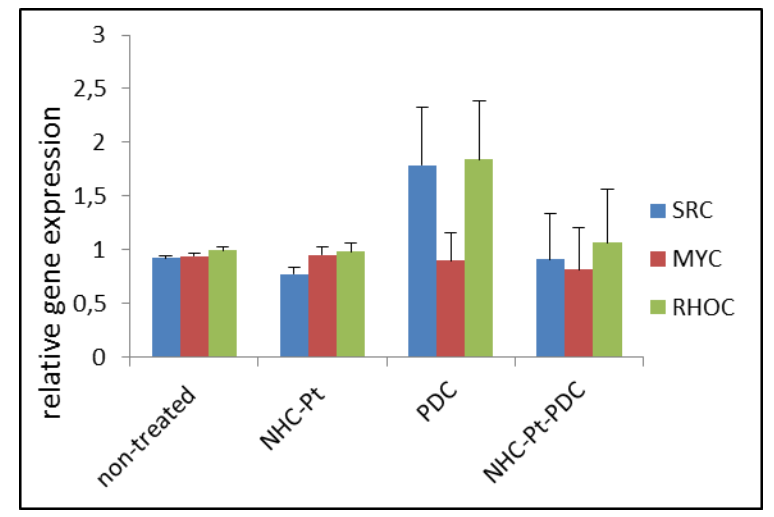

Figure 10: Relative Gene expression. The mRNA level of the SRC, MYC and RHOC genes were measured in A2780 by q-RT-PCR after 96 hours with the compounds at doses that induce $75 \%$ growth inhibition. The values were normalized using both $\beta$-actin and GAPDH.

In conclusion, based on our in solution in vitro experiments, we propose that the PDC moiety of the conjugate NHC-Pt-PDC can recognize the G-quadruplex structures from telomeric sequences, thereby directing the NHC-Pt moiety to these structures that induces in situ metal coordination. Our in cellulo experiments indicate that the conjugate compound is able to induce a loss of TRF2 from the telomeres which is increased as compared to its respective constitutive moieties alone NHC-Pt or PDC. A synergistic mechanism of action between both entities is therefore strongly suggested. Until now, we have identified telomeres as the sole target of the conjugate compound, in cellulo. This is consistent with the localisation of PDC previously described ${ }^{(15)(16)}$. Alternatively, lower repair efficiency of DNA adducts at telomeres as compared to other genomic regions ${ }^{\left({ }^{(8)}\right.}$ may also explain why the biological effects are localized at telomeres. Therefore to gain deeper insight into the specificity of action of the conjugate NHC-Pt-PDC and in 
particular to identify other potential targeted sequences further investigation using high-throughput sequencing of the genome and of the transcriptome of the treated cells are strongly required. 


\section{Experimental part :}

\section{Synthesis.}<smiles>COC(=O)c1cc(Cl)cc(C(=O)OC)n1</smiles>

\section{2,6-Dimethyl ester 4-chloropyridine.}

In a $50 \mathrm{ml}$ round-bottomed flask, phenylphosphonic dichloride $(3.07 \mathrm{~mL}, 21.7 \mathrm{mmol}, 4.0$ equiv.) was added to chelidamic acid $(1.00 \mathrm{~g}, 5.43 \mathrm{mmol})$ and the reaction mixture was heated at $120{ }^{\circ} \mathrm{C}$ for $2 \mathrm{~h}$ under argon. After cooling, anhydrous $\mathrm{MeOH}(20 \mathrm{~mL})$ was added slowly. The mixture was stirred vigorously for $1 \mathrm{~h}$ and concentrated to dryness under reduced pressure. The residue was dissolved in $\mathrm{CH}_{2} \mathrm{Cl}_{2}(20 \mathrm{~mL})$. The solution was washed with $\mathrm{H}_{2} \mathrm{O}(2 \mathrm{x})$ and with half-saturated $\mathrm{NaHCO}_{3}$ solution (2x). The organic phase was dried over $\mathrm{MgSO}_{4}$, filtered and evaporated to dryness. The residue was recrystallised from $\mathrm{MeOH}$ affording the desired chloropyridine (846 mg, $68 \%$ yield) as white needles. ${ }^{1} \mathbf{H}$ NMR (300 MHz, $\left.\mathrm{CDCl}_{3}\right): \delta 8.30$ (s, 2H), 4.04 (s, 6H). ${ }^{13} \mathbf{C}$ NMR (75 MHz, $\left.\mathrm{CDCl}_{3}\right): \delta \quad 164.1,149.4,146.9,128.3,53.5$. LRMS (ESI-MS): $m / z=252.0[\mathrm{M}+\mathrm{Na}]^{+}$.<smiles>O=C(O)c1cc(Cl)cc(C(=O)O)n1</smiles>

\section{4-Chloropyridine-2,6-dicarboxylic acid.}

To a solution of 2,6-dimethyl ester 4-chloropyridine $(846 \mathrm{mg}, 3.68 \mathrm{mmol})$ in THF (15 ml) was added a solution of lithium hydroxide ( $353 \mathrm{mg}, 14.74 \mathrm{mmol}, 4.0$ equiv.) in $\mathrm{H}_{2} \mathrm{O}$ $(5 \mathrm{ml})$. The mixture was stirred at $\mathrm{RT}$ for $3 \mathrm{~h}$ and then THF was removed under reduced pressure. The residue was slightly acidified with concentrated $\mathrm{HCl}$ until a precipitate is formed. The precipitate was filtered off, washed with water and dried, affording the desired 4-chloropyridine-2,6dicarboxylic acid (734 mg, 99\% yield) as a white solid. ${ }^{1} \mathbf{H}$ NMR (300 MHz, DMSO-d 6 ): $\delta 8.23$ (s, 2H) ppm. ${ }^{13}$ C NMR (75 MHz, DMSO-d 6 ): $\delta 164.6,150.0,145.3,127.3$ ppm. LRMS (ESI-MS): $224.1[\mathrm{M}+\mathrm{Na}]^{+}$.

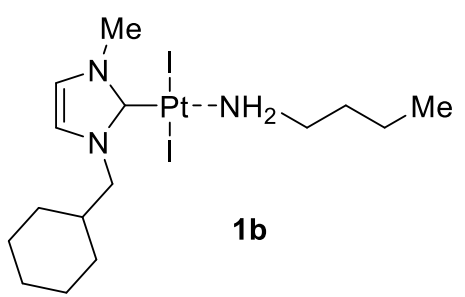

\section{trans-Diiodo( $N$-butylamine)[1-(cyclohexylmethyl)-3-methylimidazol-2- ylidene]platinum (1b).}

A solution of $\mathrm{I}_{2}\left(91 \mathrm{mg}, 357 \mu \mathrm{mol}, 1.0\right.$ equiv.) in dry toluene $(5 \mathrm{~mL})$ at $0{ }^{\circ} \mathrm{C}$ was added under argon to a solution of the platinum complex $\mathbf{3}$ (200 $\mathrm{mg}, 357$ $\mu$ mol, 1.0 equiv.) in dry toluene $(5 \mathrm{~mL})$. After $10 \mathrm{~min}$ stirring at $0{ }^{\circ} \mathrm{C}$, a solution of $n$-butylamine ( $36 \mu \mathrm{L}, 357 \mu$ mol, 1.0 equiv.) in a $1: 1$

$\mathrm{DCM} /$ methanol mixture $(10 \mathrm{~mL})$ was added and the mixture was stirred at RT overnight. After concentration under vacuo, the crude residue was purified by chromatography on silica gel with a gradient of petroleum ether/EtOAc (0:100 to 70:30) to give the desired product $\mathbf{1 b}(200 \mathrm{mg}, 80 \%)$ as a yellow solid $\left(R_{\mathrm{f}}=0.5 \mathrm{in}\right.$ petroleum ether/EtOAc 7:3). ${ }^{1} \mathbf{H}$ NMR $\left(\mathrm{CDCl}_{3}, 300.2 \mathrm{MHz}\right) \delta 6.77(\mathrm{~d}, J=1.8 \mathrm{~Hz}, 1 \mathrm{H}, \mathrm{NCH}=), 6.75(\mathrm{~d}, J=$ $1.8 \mathrm{~Hz}, 1 \mathrm{H}, \mathrm{NCH}=), 4.07$ (d, $\left.J=7.6 \mathrm{~Hz}, 2 \mathrm{H}, \mathrm{CH}_{2}\right), 3.85$ (s, 3H, $\left.\mathrm{CH}_{3}\right), 3.07-2.89\left(\mathrm{~m}, 2 \mathrm{H}, \mathrm{CH}_{2}\right), 2.90(\mathrm{bs}, 2 \mathrm{H}$, $\mathrm{NH}_{2}$ ), 2.51-2.36 (m, 1H, CH), 1.77-1.67 (m, 3H), 1.65 (hex, $\left.J=7.6 \mathrm{~Hz}, 2 \mathrm{H}, \mathrm{CH}_{2}\right), 1.40$ (hex, $J=7.6 \mathrm{~Hz}, 2 \mathrm{H}$, $\left.\mathrm{CH}_{2}\right), 1.31-1.15(\mathrm{~m}, 3 \mathrm{H}), 1.06-0.96(\mathrm{~m}, 2 \mathrm{H}) ; 0.95\left(\mathrm{t}, J=7.6 \mathrm{~Hz}, 2 \mathrm{H}, \mathrm{CH}_{3}\right) .{ }^{13} \mathbf{C} \mathbf{~ N M R}\left(\mathrm{CDCl}_{3}, 75.5 \mathrm{MHz}\right) \delta$ $138.7(\mathrm{C}), 121.5(\mathrm{NCH}=), 121.3(\mathrm{NCH}=), 57.5\left(\mathrm{NCH}_{2}\right), 45.3\left(\mathrm{NCH}_{2}\right), 38.4\left(\mathrm{NCH}_{3}\right), 37.4(\mathrm{CH}), 34.2\left(\mathrm{CH}_{2}\right)$, $30.9\left(\mathrm{CH}_{2}\right), 26.4\left(\mathrm{CH}_{2}\right), 25.7\left(\mathrm{CH}_{2}\right), 19.8\left(\mathrm{CH}_{2}\right), 13.8\left(\mathrm{CH}_{3}\right)$. IR: $v_{\max }=3286,3225,3128,2922,2851,1571$, 1465, 1448, 1418, 1231, 1081, 728, 699. HRMS (ESI+) calcd. for $\mathrm{C}_{15} \mathrm{H}_{29} \mathrm{~N}_{3} \mathrm{I}^{195} \mathrm{Pt}$ [M-I] $]^{+}: 573.1054$, Found 573.1035 ; calcd. for $\mathrm{C}_{17} \mathrm{H}_{32} \mathrm{~N}_{4} \mathrm{I}^{195} \mathrm{Pt}\left[\mathrm{M}-\mathrm{I}+\mathrm{CH}_{3} \mathrm{CN}\right]^{+}:$614.1319, Found 614.1304. 
<smiles>O=C(Nc1cnc2ccccc2c1)c1cc(Cl)cc(C(=O)Nc2cnc3ccccc3c2)n1</smiles>

CI-PDC

\section{4-Chloro- $N^{2}, N^{6}$-di(quinolin-3-yl)pyridine-2,6-dicarboxamide}

In a $250 \mathrm{ml}$ round bottomed flask 4-chloropyridine-2,6-dicarboxylic acid (725 mg, $3.60 \mathrm{mmol}, 1.0$ eq.) was dissolved in a 9:1 $\mathrm{CH}_{2} \mathrm{Cl}_{2} / \mathrm{DMF}$ mixture (35 ml). Quinolin-3-amine (1.14 g, $7.91 \mathrm{mmol}, 2.2$ eq.), HOBt (138 mg, $0.90 \mathrm{mmol}, 0.25$ eq.) and EDCI (1.72 g, $8.99 \mathrm{mmol}, 2.5$ eq.) were added and the mixture was stirred at RT overnight. The formed precipitate was filtered off, washed with $\mathrm{H}_{2} \mathrm{O}$ and dried under vacuum to afford Cl-PDC (1.05 g, 64\% yield) as a white solid. ${ }^{1} \mathbf{H}$ NMR (300 MHz, DMSO-d $) \delta$ $11.48(\mathrm{~s}, 2 \mathrm{H}), 9.37$ (s, 2H), 8.98 (s, 2H), $8.46(\mathrm{~s}, 2 \mathrm{H}), 8.07-8.04(\mathrm{~m}, 4 \mathrm{H})$, $7.74(\mathrm{t}, J=7.0 \mathrm{~Hz}, 2 \mathrm{H}), 7.65(\mathrm{t}, J=7.0 \mathrm{~Hz}, 2 \mathrm{H})$. LRMS (ESI-MS): $m / z=452.1[\mathrm{M}-\mathrm{H}]^{-}$. HRMS (ESI+) calcd. for $\mathrm{C}_{25} \mathrm{H}_{17} \mathrm{ClN}_{5} \mathrm{O}_{2}[\mathrm{M}+\mathrm{H}]^{+}:$454.1071, Found 454.1055.<smiles>NCCCCCNc1cc(C(=O)Nc2cnc3ccccc3c2)nc(C(=O)Nc2cnc3ccccc3c2)c1</smiles>

\section{4-[(4-Aminobutyl)amino]- $N^{2}, N^{6}$-di(quinolin-3-yl)pyridine-2,6- dicarboxamide}

In a $100 \mathrm{ml}$ round-bottomed flask, 4-chloro- $N^{2}, N^{6}$-di(quinolin-3yl)pyridine-2,6-dicarboxamide Cl-PDC (1.00 g, $2.20 \mathrm{mmol}, 1.0$ equiv.) was suspended in butane-1,4-diamine $(33.5 \mathrm{~mL}, 551 \mathrm{mmol}, 150$ equiv.) affording a pale yellow suspension. Triethylamine $(0.32 \mathrm{~mL}, 2.20 \mathrm{mmol}$, 1.0 equiv.) was added and the reaction mixture was stirred at $90{ }^{\circ} \mathrm{C}$ overnight. The excess of butane-1,4-diamine was removed under vacuum and the red oily residue was added to a saturated solution of $\mathrm{NaHCO}_{3}$. The white precipitate was filtered off, washed with water and ether and dried under vacuum affording $\mathbf{N H}_{\mathbf{2}}$-PDC $(0.899 \mathrm{~g}, 81 \%)$ as a white powder. ${ }^{1} \mathbf{H}$ NMR $\left(300 \mathrm{MHz}, \mathrm{CDCl}_{3}\right): \delta 11.31(\mathrm{~s}, 2 \mathrm{H}), 9.34(\mathrm{~s}, 2 \mathrm{H}), 8.96$ (s, $2 \mathrm{H}), 8.03(\mathrm{~d}, \mathrm{~J}=8.4 \mathrm{~Hz}, 4 \mathrm{~Hz}), 7.70(\mathrm{t}, J=8.1 \mathrm{~Hz}, 2 \mathrm{H}), 7.64(\mathrm{t}, J=8.1 \mathrm{~Hz}, 2 \mathrm{H}), 7.57-7.49$ (m, 2H), $3.22(\mathrm{~s}, 2 \mathrm{H}), 2.61(\mathrm{~m}, 2 \mathrm{H}), 1.63(\mathrm{~m}, 2 \mathrm{H}), 1.49(\mathrm{~s}, 2 \mathrm{H}) .{ }^{13} \mathbf{C ~ N M R}\left(75 \mathrm{MHz}, \mathrm{CDCl}_{3}\right): \delta . \mathbf{L R M S}$ (ESI-MS): $m / z=506.2[\mathrm{M}+\mathrm{H}]^{+}$.

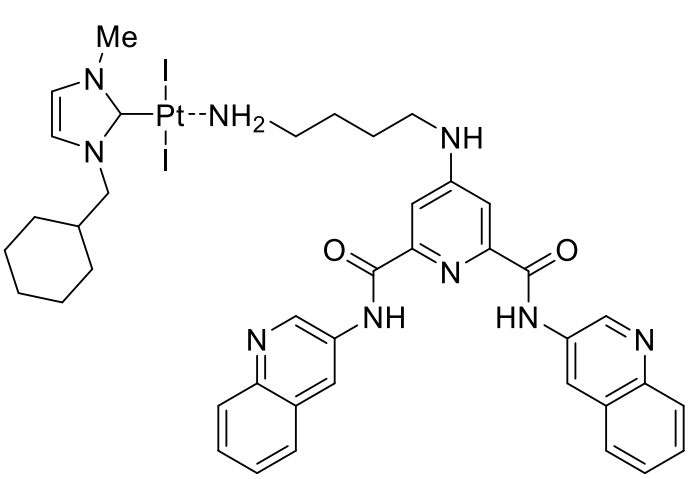

NHC-Pt-PDC ${ }^{N}$
trans-Diiodo\{4-[( $N^{2}, N^{6}$-di(quinolin-3-yl)-2,6-dicarboxamide pyridin-4-yl)-4-yl)amino]butylamine $\}[1-$ (cyclohexylmethyl)-3-methylimidazol-2-ylidene]platinum NHC-Pt-PDC ${ }^{\mathrm{N}}$

A solution of $\mathrm{I}_{2}(38.7 \mathrm{mg}, 152 \mu \mathrm{mol}, 1.0$ equiv.) in toluene (5 $\mathrm{mL}$ ) was added under argon to a solution of the NHCdivinyldisiloxane platinum ${ }^{(0)}$ complex $3(85.3 \mathrm{mg}, 152 \mu \mathrm{mol}$, 1.0 equiv. $)$ in dry toluene $(4 \mathrm{~mL})$ at $0{ }^{\circ} \mathrm{C}$. After $10 \mathrm{~min}$ of stirring at $0{ }^{\circ} \mathrm{C}$, a solution of $\mathbf{N H}_{2}$-PDC $(77 \mathrm{mg}, 152 \mu \mathrm{mol}, 1.0$ equiv.) in dry $\mathrm{MeOH}(0.7 \mathrm{~mL})$ was added and the mixture was stirred at RT overnight. After concentration under vacuo, the crude residue was purified by chromatography on silica gel with a petroleum ether/EtOAc gradient (65:35 to 30:70) to give the desired complex NHC-Pt-PDC ${ }^{\mathbf{N}}(127 \mathrm{mg}, 74 \%)$ as a yellow solid $\left(R_{\mathrm{f}}=0.4\right.$ in petroleum ether/EtOAc 1:1). ${ }^{1} \mathbf{H}$ NMR $\left(\mathrm{CDCl}_{3}, 300.2 \mathrm{MHz}\right) \delta 10.03(\mathrm{~s}, 2 \mathrm{H}, \mathrm{NH}), 9.07(\mathrm{~d}, J=2.1 \mathrm{~Hz}, 2 \mathrm{H}, \mathrm{CH}), 8.65(\mathrm{~d}$, $J=2.1 \mathrm{~Hz}, 2 \mathrm{H}, \mathrm{CH}), 7.98(\mathrm{~d}, J=8.0 \mathrm{~Hz}, 2 \mathrm{H}, \mathrm{CH}), 7.66(\mathrm{~d}, J=8.0 \mathrm{~Hz}, 2 \mathrm{H}, \mathrm{CH}), 7.59(\mathrm{t}, J=8.0 \mathrm{~Hz}, 2 \mathrm{H}$, $\mathrm{CH}), 7.46(\mathrm{t}, J=8.0 \mathrm{~Hz}, 2 \mathrm{H}, \mathrm{CH}), 7.45(\mathrm{bs}, 2 \mathrm{H}), 6.75(\mathrm{~d}, J=2.0 \mathrm{~Hz}, 1 \mathrm{H}, \mathrm{NCH}=), 6.72(\mathrm{~d}, J=2.0 \mathrm{~Hz}, 1 \mathrm{H}$, $\mathrm{NCH}=), 5.64-5.59(\mathrm{~m}, 1 \mathrm{H}, \mathrm{NH}), 4.05\left(\mathrm{~d}, J=7.8 \mathrm{~Hz}, 2 \mathrm{H}, \mathrm{CH}_{2}\right), 3.82\left(\mathrm{~s}, 3 \mathrm{H}, \mathrm{CH}_{3}\right), 3.24-3.17\left(\mathrm{~m}, 2 \mathrm{H}, \mathrm{CH}_{2} \mathrm{~N}\right)$, 
3.11-3.01 (m, 4H, $\left.\mathrm{NH}_{2}, \mathrm{NCH}_{2}\right), 2.43-2.32(\mathrm{~m}, 1 \mathrm{H}, \mathrm{CH}), 1.82-1.60(\mathrm{~m}, 9 \mathrm{H}), 1.25-1.15(\mathrm{~m}, 3 \mathrm{H}), 1.01-0.89$ (m, 2H). ${ }^{13} \mathrm{C}$ NMR $\left(\mathrm{CDCl}_{3}, 75.5 \mathrm{MHz}\right) \delta 163.2(\mathrm{C}), 156.1$ (C), $149.2(\mathrm{C}), 145.4(\mathrm{C}), 144.8(\mathrm{CH}), 138.0(\mathrm{C})$, $131.2(\mathrm{C}), 129.0(\mathrm{CH}), 128.7(\mathrm{CH}), 128.1(\mathrm{C}), 127.8(\mathrm{CH}), 127.4(\mathrm{CH}), 124.7(\mathrm{CH}), 121.5(\mathrm{NCH}=), 121.4$ $(\mathrm{NCH}=), 57.4\left(\mathrm{NCH}_{2}\right), 45.1\left(\mathrm{NCH}_{2}\right), 42.6\left(\mathrm{CH}_{2} \mathrm{~N}\right), 38.4\left(\mathrm{NCH}_{3}\right), 37.4(\mathrm{CH}), 30.9\left(\mathrm{CH}_{2}\right), 28.9\left(\mathrm{CH}_{2}\right), 26.4$ $\left(\mathrm{CH}_{2}\right), 26.0\left(\mathrm{CH}_{2}\right), 25.7\left(\mathrm{CH}_{2}\right)$. IR: $v_{\max }=3301,2925,2852,1672,1606,1533,1491,1468,1368,1230,990$, 906, 730. HRMS (ESI+) calcd. for $\mathrm{C}_{40} \mathrm{H}_{46} \mathrm{~N}_{9} \mathrm{O}_{2} \mathrm{I}_{2}{ }^{195} \mathrm{Pt}[\mathrm{M}+\mathrm{H}]^{+}:$1133.1512, Found 1133.1553. HRMS (ESI-) calcd. for $\mathrm{C}_{40} \mathrm{H}_{44} \mathrm{~N}_{9} \mathrm{O}_{2} \mathrm{I}_{2}{ }^{195} \mathrm{Pt}[\mathrm{M}-\mathrm{H}]-1131.1355$, Found 1131.1331 .

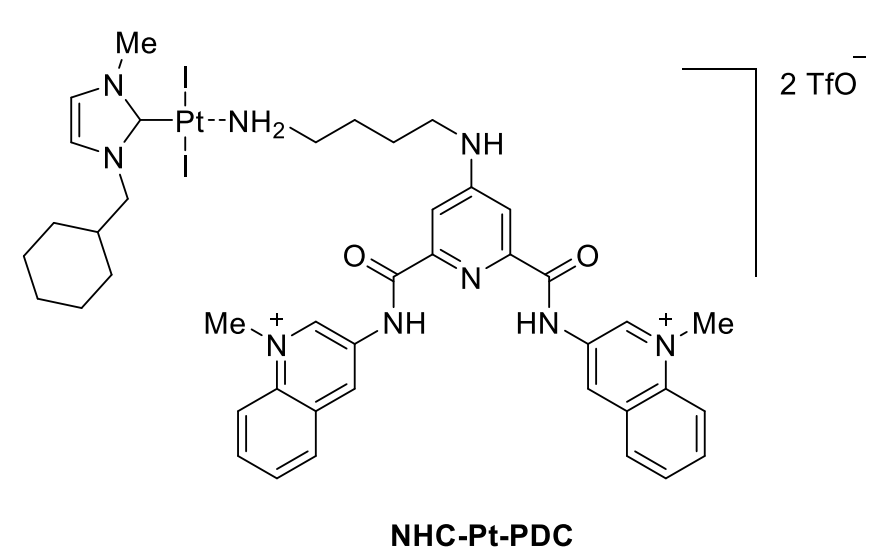

trans-Diiodo $\left\{4-\left[\left(N^{2}, N^{6}\right.\right.\right.$-di(methylquinolinium-3yl)-2,6-dicarboxamide pyridin-4-yl)-4yl)amino]butyl-amine\}[1-(cyclohexylmethyl)-3methylimidazol-2-ylidene]platinum bis(trifluoromethanesulfonate) - NHC-Pt-PDC

To a solution of the platinum complex NHC-PtPDC $^{\mathbf{N}}(42.5 \mathrm{mg}, \quad 37.5 \mu \mathrm{mol})$ in dry $1,2-$ dichloroethane $(1.1 \mathrm{~mL})$ at $0{ }^{\circ} \mathrm{C}$ under argon was added methyl trifluoromethanesulfonate $(8.5 \mu \mathrm{L}$, $75 \mu \mathrm{mol}, 2.0$ equiv.). The mixture was stirred at 0 ${ }^{\circ} \mathrm{C}$ for $5 \mathrm{~min}$ and then at RT for $1 \mathrm{~h}$. The solvent was evaporated to give the desired complex NHC-Pt-PDC (54.8 mg, quantitative yield). ${ }^{1} \mathbf{H}$ NMR $\left(\mathrm{CDCl}_{3}\right.$, $500.1 \mathrm{MHz}) \delta 11.57$ (bs, 2H, NH), 10.29 (s, 2H, CH), 10.00 (s, 2H, CH), 8.19 (d, J = 8.1 Hz, 2H, CH), 8.13 $(\mathrm{d}, J=8.1 \mathrm{~Hz}, 2 \mathrm{H}, \mathrm{CH}), 8.00(\mathrm{t}, J=8.1 \mathrm{~Hz}, 2 \mathrm{H}, \mathrm{CH}), 7.88(\mathrm{t}, J=8.1 \mathrm{~Hz}, 2 \mathrm{H}, \mathrm{CH}), 7.55(\mathrm{~s}, 2 \mathrm{H}, \mathrm{CH}), 6.80(\mathrm{~d}$, $J=1.8 \mathrm{~Hz}, 1 \mathrm{H}, \mathrm{NCH}=), 6.76(\mathrm{~d}, J=1.8 \mathrm{~Hz}, 1 \mathrm{H}, \mathrm{NCH}=), 5.40(\mathrm{bt}, J=5.1 \mathrm{~Hz}, 1 \mathrm{H}, \mathrm{NH}), 4.85\left(\mathrm{~s}, 6 \mathrm{H}, \mathrm{CH}_{3}\right)$, $4.08\left(\mathrm{~d}, J=7.6 \mathrm{~Hz}, 2 \mathrm{H}, \mathrm{CH}_{2}\right), 3.85\left(\mathrm{~s}, 3 \mathrm{H}, \mathrm{CH}_{3}\right), 3.38\left(\mathrm{bq}, J=5.8 \mathrm{~Hz}, 2 \mathrm{H}, \mathrm{CH}_{2} \mathrm{~N}\right), 3.18-3.13\left(\mathrm{~m}, 2 \mathrm{H}, \mathrm{NCH}_{2}\right)$, 3.05-3.02 (m, $\left.2 \mathrm{H}, \mathrm{NH}_{2}\right), 2.46-2.38(\mathrm{~m}, 1 \mathrm{H}, \mathrm{CH}), 1.95-1.89\left(\mathrm{~m}, 2 \mathrm{H}, \mathrm{CH}_{2}\right), 1.89-1.82\left(\mathrm{~m}, 2 \mathrm{H}, \mathrm{CH}_{2}\right), 1.73-1.64$ (m, 5H), 1.25-1.15 (m, 3H), 1.03-0.95 (m, 2H). ${ }^{13} \mathbf{C ~ N M R ~}\left(\mathrm{CDCl}_{3}, 125.8 \mathrm{MHz}\right) \delta 164.0(\mathrm{C}), 156.2(\mathrm{C}), 148.3$ (C), $147.4(\mathrm{CH}), 138.0(\mathrm{C}), 135.2(\mathrm{C}), 133.8(\mathrm{C}), 133.4(\mathrm{CH}), 132.5(\mathrm{CH}), 130.6(\mathrm{CH}), 130.2(\mathrm{CH}), 130.0$ (C), $121.6(\mathrm{NCH}=), 121.5(\mathrm{NCH}=), 120.1\left(\mathrm{q}, J_{\mathrm{C}-\mathrm{F}}=321.4 \mathrm{~Hz}, \mathrm{CF}_{3}\right), 117.6(\mathrm{CH}), 57.4\left(\mathrm{NCH}_{2}\right), 45.7\left(\mathrm{NCH}_{3}\right)$, $45.2\left(\mathrm{NCH}_{2}\right), 42.8\left(\mathrm{CH}_{2} \mathrm{~N}\right), 38.5\left(\mathrm{NCH}_{3}\right), 37.4(\mathrm{CH}), 30.9\left(\mathrm{CH}_{2}\right), 29.9\left(\mathrm{CH}_{2}\right), 26.4\left(\mathrm{CH}_{2}\right), 26.0\left(\mathrm{CH}_{2}\right), 25.8$ $\left(\mathrm{CH}_{2}\right)$. HRMS (ESI+) calcd. for $\mathrm{C}_{43} \mathrm{H}_{51} \mathrm{~F}_{3} \mathrm{I}_{2} \mathrm{~N}_{9} \mathrm{O}_{5} \mathrm{~S}^{195} \mathrm{Pt}\left[\mathrm{M}-\mathrm{CF}_{3} \mathrm{SO}_{3}\right]^{+}: 1311.1423$, Found 1311.1482. 


\section{HT-G4-FID}

G4-FID measurements were performed on a FLUOstar Omega microplate reader (BMG Labtech) with a 96 wells black quartz microplate (Hellma)as described previously ${ }^{(59)}$. Typically each well contains an aqueous solution of pre-folded DNA $(0.25 \mu \mathrm{M}$ in DNA strand), Thiazole Orange (TO, $0.5 \mu \mathrm{M})$ in $10 \mathrm{mM}$ lithium cacodylate buffer ( $\mathrm{pH}$ 7.3), $100 \mathrm{mM} \mathrm{KCl}$, and increasing concentration of $\mathrm{G} 4$ binding compound ( 0 10 molar equiv.) in a final volume of $200 \square 1$. The fluorescence area of the initial mixture (DNA + TO) was designated as $\mathrm{FA}_{0}$, and that measured in presence of G4-binding compound was designated as FA. The percentage of $\mathrm{TO}$ displacement was calculated from the variation of fluorescence area $(\% \mathrm{TO}$ displacement $=$ $\left.100-\mathrm{FA} / \mathrm{FA}_{0} * 100\right)$ and plotted as function of the ligand concentration. The $\mathrm{DC}_{50}$ corresponds to the compound concentration inducing a TO displacement of 50\%. TO (thiazole orange) and cacodylic acid were purchased from Aldrich and used without further purification. Stock solutions of TO and NHC-PtPDCconjugate (2 $\mathrm{mM}$ in DMSO) were used. Oligonucleotides purified by reverse phase HPLC were purchased from Eurogentec (Belgium) and folded before experiment by heating for $5 \mathrm{~min}$ at $90^{\circ} \mathrm{C}$ followed by slow cooling at room temperature. Sequences: $22 \mathrm{AG}$ corresponds to the human telomeric repeat ${ }^{(84)}$ : [5'$\mathrm{AG}_{3}\left(\mathrm{~T}_{2} \mathrm{AG}_{3}\right)_{3}-3^{\prime}$ ']; c-kit2 [5'- $\left.\mathrm{G}_{3} \mathrm{CG}_{3}(\mathrm{CG})_{2} \mathrm{AG}_{3} \mathrm{AG}_{4}-3^{\prime}\right]$ is a sequence of the c-kit oncogene promoter ${ }^{(85)}$, cmyc [5'- $\mathrm{TGAG}_{3} \mathrm{TG}_{3} \mathrm{TAG}_{3} \mathrm{TG}_{3} \mathrm{TA}_{2}-3^{\prime}$ ] is a sequence from the c-myc promoter ${ }^{\left({ }^{86)},\right.} 25 \mathrm{Ceb}$ is a human minisatellite sequence ${ }^{(60)}:\left[5^{\prime}-\mathrm{AG}_{3} \mathrm{TG}_{3} \mathrm{TGTA}_{2} \mathrm{GTGTG}_{3} \mathrm{TG}_{3} \mathrm{~T}-3^{\prime}\right]$ and ds26 is an autocomplementary duplex control: [5'- $\mathrm{CA}_{2} \mathrm{TCG}_{2} \mathrm{ATCGA}_{2} \mathrm{~T}_{2} \mathrm{CGATC}_{2} \mathrm{GAT}_{2} \mathrm{G}-3$ ']

\section{In vitro platination studies}

The telomeric sequence $\mathrm{AG}_{3}\left(\mathrm{~T}_{2} \mathrm{AG}_{3}\right)_{3}$ was 5 , radiolabeled using ${ }^{32} \mathrm{P} \gamma$-ATP, and then folded in $\mathrm{G} 4$ structure or hybridized with its complementary strand in order to get the duplex structure at $100 \mu \mathrm{M}$ in $50 \mathrm{mM}$ $\mathrm{KClO}_{4}$ solutions. After incubation of DNA with different trans-platinum complexes (2.5 eq), the platination products were isolated by gel electrophoresis. The platinum binding site was determined using 3'exonuclease digestion as already described ${ }^{(47)}$. The digested fragments were purified from gel and then incubated overnight with $0.2 \mathrm{M} \mathrm{NACN}$ at $30^{\circ} \mathrm{C}$. Deplatinated fragments were again migrated on a denaturing gel electrophoresis together with a sample partially digested allowing the determination of the fragments length and consequently the 3'exonuclease stop and the platinated base. For the intramolecular kinetic competitions experiments, the procedure was followed as described ${ }^{(68)}$. The $35 \mathrm{G} 4$ was designed in order to adopt a G4 structure of the telomeric sequence at it 3' extremity a sequence able to hybridize with a sequence containing a GXG sequence; 35G4: $\mathrm{AG}_{3}\left(\mathrm{~T}_{2} \mathrm{AG}_{3}\right)_{3}$ TATTACACATTAT. 13GXG: ATAATGTGTAATA:

\section{In cells studies}

Cell culture. The ovarian carcinoma cell lines were purchased from ECACC (Salisbury, UK) and were grown in complete RPMI medium supplemented with $10 \%$ fetal calf serum, in the presence of penicillin, streptomycin. The resistance of A2780/DDP cells to cisplatin was maintained by monthly treatment with $1 \mu \mathrm{M}$ cisplatin for 4 days. Cells were treated with various concentrations of NHC-Pt, NHC-Pt-PDC ${ }^{\mathbf{N}}$, NHC- 
Pt-PDC and PDC at $37^{\circ} \mathrm{C}$ under humidity and $5 \% \mathrm{CO}_{2}$ conditions for $96 \mathrm{~h}$. Cellular growth was quantified

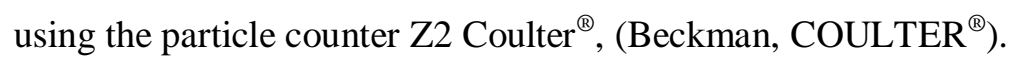

\section{Cell cycle analysis.}

A2780 and A2780/DDP cells (25,000 cells/well in 96-well microplates) were exposed for 24 and $48 \mathrm{~h}$ at $37^{\circ} \mathrm{C}$ under $5 \% \mathrm{CO}_{2}$ to $\mathrm{Pt}-\mathrm{NHC}$ complexes in $100 \mathrm{~mL}$ complete RPMI medium. Controls received the same volume of DMSO (1\% final volume). Culture media were carefully collected and gently centrifuged to collect floating cells, adherent cells harvested after addition of trypsin, mixed with the pellet of floating cells, washed with PBS and fixed in ice-cold $70 \%$ ethanol. After $2 \mathrm{~h}$ at $4^{\circ} \mathrm{C}$, cells were spun down by centrifugation, washed with $2 \%$ FCS in PBS and stained with $50 \mathrm{mg} / \mathrm{mL}$ propidium iodide in hypotonic buffer (3.4 mM Na citrate, $\mathrm{pH} 7.4,0.2 \%$ Triton X-100) in the presence of RNase A $(50 \mathrm{mg} / \mathrm{mL})$ for $30 \mathrm{~min}$ at room temperature shielding away from light, before be analyzed by flow cytometry with a Guava Easycyte cytometer (Millipore). Cell populations were quantified using Modfit LT (Verity Software House).

\section{Platinum uptake measurement}

The platinum cellular uptake was quantified by ICP-MS (inductively coupled plasma mass spectrometry) on cellular pellet (5E $\mathrm{E}^{+06}$ cells) or DNA extract of A2780 or A2780cis cells treated with various concentrations of NHC-Pt, NHC-Pt-PDC ${ }^{\text {N }}$ or NHC-Pt-PDC during 96h. ICP-MS has been used also for monitoring the solubilization of platinum complexes in the aqueous solution.

Gene Expression Analysis. A2780 were cultured for 96 hours with or without the compounds, then total RNA were extracted using Trizol ${ }^{\circledR}$ (Life Technologies), and the cDNA was prepared using the Transcriptor First Strand cDNA Synthesis Kit (Roche) and oligo dT. q-PCR were performed using the LightCycler® FastStart DNA Master SYBR Green I (Roche) on a LightCycler® 2.0 instrument. Crossing-points (CP) were determined using the second derivative maximum method. GAPDH and $\beta$-Actin were used to normalize the values. TERRA was quantified using two previously described methods ${ }^{(87)(88)}$. Briefly, the level of total TERRA was measured by preparing the cDNA using random hexamers followed by telomere PCR. Chromosome specific TERRA was quantified by preparing the cDNA with a TERRA and an actin primer during the reverse transcription. Then, TERRA from chromosome 10q were amplified with primers specific for the subtelomeric region of this chromosome. The primers used were: SRC-F 5'ACCACCTTTGTGGCCCTCTATG-; SRC-R 5'-GCCACCAGTCTCCCTCTGTGTT-; MYC-F 5'CGTCTCCACACATCAGCACAA-; MYC-R 5'-CACTGTCCAACTTGACCCTCTTG-; RHOC-F 5'ACCTGCCTCCTCATCGTCTTC-; $\quad$ RHOC-R 5'-CACCTGCTTGCCGTCCAC-; $\quad$ GAPDH-F 5'GAAATCCCATCACCATCTTCCAGG-; GAPDH-R 5'-GAGCCCCAGCCTTCTCCATG-; ACTIN-F 5'TCCCTGGAGAAGAGCTACGA-; ACTIN-R 5'-AGCACTGTGTTGGCGTACAG-. TERRA-RT CCCTAACCCTAACCCTAACCCTAACCCTAA; B-actin-RT 5'-AGTCCGCCTAGAAGCATTTG; Chr 10q-F 5'-GAATCCTGCGCACCGAGAT-3'; Chr 10q-R 5'-CTGCACTTGAACCCTGCAATAC-3' (17). 
PCR telomere length. Genomic DNA of A2780 treated cells with NHC-Pt, NHC-Pt-PDC ${ }^{\mathbf{N}}$, NHC-Pt-PDC or PDC during four days at doses inducing $75 \%$ growth inhibition was extracted using the DNeasy Blood \& Tissue Kit (QIAGEN) and the relative telomere length were determined by real-time PCR using the method described by Cawthon ${ }^{(89)}$, adapted for a LightCycler instrument ${ }^{(90)}$.

Immunofluorescence Assays. A2780 cells plated on coverslips in 6-well plates. After 4 days of treatment with NHC-Pt, NHC-Pt-PDC ${ }^{\mathrm{N}}$, NHC-Pt-PDC or PDC during 96h at doses inducing 75\% growth inhibition, cells were washed with phosphate-buffered saline (PBS), then fixed 10 minutes in $4 \%$ formaldehyde. After a wash with PBS, cells were permeabilised 2 min using 0.5\% Triton X-100 and washed with PBS. The cells were incubated in blocking buffer (5\% bovine serum albumin in PBS) for $30 \mathrm{~min}$ before being incubated for $1 \mathrm{~h}$ with the primary mouse monoclonal antibody against TRF2 (clone 4A794). After three washes with PBS, the cells were incubated for an additional $1 \mathrm{~h}$ with the Alexa Fluor 488-conjugated secondary antibody (Alexa Fluor 488 goat anti-mouse IgG; Life Technologies). Nuclei were labeled using TO-PRO®-3 (Life Technologies) and the coverslides were mounted with Vectashield ${ }^{\mathrm{TM}}$. Acquisitions were performed on a confocal microscope (Zeiss LSM510) in the SCM (Faculté des Sciences Fondamentales et Biomédicales Université Paris Descartes). ImageJ software (NCBI) was used to project the z-stacks and count the number of TRF2 spots in nuclei.

\section{Acknowledgments}

The authors sincerely acknowledge the SCM (Service Commun de Microscopie - Faculté des Sciences Fondamentales et Biomédicales - Université Paris Descartes) Authors thank the 'Institut National du Cancer' (INCa) and the Canceropôle Île de France for supporting this work in the frame of the "PlBio 2010" action.

Supporting Information Available: NMR spectra of complexes 1b, NHC-Pt-PDC ${ }^{\mathrm{N}}$ and NHC-Pt-PDC. This material is available free of charge via the Internet at http://pubs.acs.org. 


\section{References}

1. Hurley, L. H. (2002) DNA and its associated processes as targets for cancer therapy, Nat. Rev. Cancer 2, 188-200.

2. Neidle, S., and Thurston, D. E. (2005) Chemical approaches to the discovery and development of cancer therapies, Nat. Rev. Cancer 5, 285-296.

3. Gnewuch, C. T., and Sosnovsky, G. (2002) Critical appraisals of approaches for predictive designs in anticancer drugs, Cell Mol. Life Sci. 59, 959-1023.

4. Takebayashi, Y., Pourquier, P., Zimonjic, D. B., Nakayama, K., Emmert, S., Ueda, T., Urasaki, Y., Kanzaki, A., Akiyama, S. I., Popescu, N., Kraemer, K. H., and Pommier, Y. (2001) Antiproliferative activity of ecteinascidin 743 is dependent upon transcription-coupled nucleotide-excision repair, Nat. Med. 7, 961-966.

5. Anders, L., Guenther, M. G., Qi, J., Fan, Z. P., Marineau, J. J., Rahl, P. B., Loven, J., Sigova, A. A., Smith, W. B., Lee, T. I., Bradner, J. E., and Young, R. A. (2014) Genome-wide localization of small molecules, Nat. Biotechnol. 32, 92-96.

6. Anandhakumar, C., Kizaki, S., Bando, T., Pandian, G. N., and Sugiyama, H. (2015) Advancing smallmolecule-based chemical biology with next-generation sequencing technologies, ChemBioChem 16, 20-38.

7. Müller, S., and Rodriguez, R. (2014) G-quadruplex interacting small molecules and drugs: from bench toward bedside, Expert Rev. Clin. Pharmacol. 7, 663-679.

8. Burge, S., Parkinson, G. N., Hazel, P., Todd, A. K., and Neidle, S. (2006) Quadruplex DNA: sequence, topology and structure, Nucleic Acids Res. 34, 5402-5415.

9. Bochman, M. L., Paeschke, K., and Zakian, V. A. (2012) DNA secondary structures: stability and function of G-quadruplex structures, Nat. Rev. Genet. 13, 770-780.

10. Balasubramanian, S., and Neidle, S. (2009) G-quadruplex nucleic acids as therapeutic targets, Curr. Opin. Chem. Biol. 13, 345-353.

11. Murat, P., and Balasubramanian, S. (2014) Existence and consequences of G-quadruplex structures in DNA, Curr. Opin. Genet. Dev. 25, 22-29.

12. Maizels, N. (2012) G4 motifs in human genes, Ann. N. Y. Acad. Sci. 1267, 53-60.

13. Gray, L. T., Vallur, A. C., Eddy, J., and Maizels, N. (2014) G quadruplexes are genomewide targets of transcriptional helicases XPB and XPD, Nat. Chem. Biol. 10, 313-318.

14. Ohnmacht, S. A., and Neidle, S. (2014) Small-molecule quadruplex-targeted drug discovery, Bioorg. Med. Chem. Lett. 24, 2602-2612.

15. Granotier, C., Pennarun, G., Riou, L., Hoffschir, F., Gauthier, L. R., De Cian, A., Gomez, D., Mandine, E., Riou, J. F., Mergny, J. L., Mailliet, P., Dutrillaux, B., and Boussin, F. D. (2005) Preferential binding of a G-quadruplex ligand to human chromosome ends, Nucleic Acids Res. 33, 4182-4190.

16. Boussin, F. D., and Granotier, C. (2011) Differential Effects of the G-Quadruplex Ligand 360A in Human Normal and Cancer Cells In DNA Repair and Human Health (Vengrova, S., Ed.), pp 559-596.

17. Rodriguez, R., Miller, K. M., Forment, J. V., Bradshaw, C. R., Nikan, M., Britton, S., Oelschlaegel, T., Xhemalce, B., Balasubramanian, S., and Jackson, S. P. (2012) Small-molecule-induced DNA damage identifies alternative DNA structures in human genes, Nat. Chem. Biol. 8, 301-310.

18. Tahara, H., Shin-Ya, K., Seimiya, H., Yamada, H., Tsuruo, T., and Ide, T. (2006) G-Quadruplex stabilization by telomestatin induces TRF2 protein dissociation from telomeres and anaphase bridge formation accompanied by loss of the 3 ' telomeric overhang in cancer cells, Oncogene 25, 1955-1966.

19. Gomez, D., Wenner, T., Brassart, B., Douarre, C., O'Donohue M, F., El Khoury, V., Shin-Ya, K., Morjani, H., Trentesaux, C., and Riou, J. F. (2006) Telomestatin induced telomere uncapping is modulated by POT1 through G-overhang extension in HT1080 human tumor cells, J. Biol. Chem. 281, 38721-38729.

20. Gomez, D., O'Donohue, M. F., Wenner, T., Douarre, C., Macadre, J., Koebel, P., Giraud-Panis, M. J., Kaplan, H., Kolkes, A., Shin-ya, K., and Riou, J. F. (2006) The G-quadruplex ligand telomestatin inhibits POT1 binding to telomeric sequences in vitro and induces GFP-POT1 dissociation from telomeres in human cells, Cancer Res. 66, 6908-6912. 
21. Piazza, A., Boule, J. B., Lopes, J., Mingo, K., Largy, E., Teulade-Fichou, M. P., and Nicolas, A. (2010) Genetic instability triggered by G-quadruplex interacting Phen-DC compounds in Saccharomyces cerevisiae, Nucleic Acids Res. 38, 4337-4348.

22. Lopes, J., Piazza, A., Bermejo, R., Kriegsman, B., Colosio, A., Teulade-Fichou, M. P., Foiani, M., and Nicolas, A. (2011) G-quadruplex-induced instability during leading-strand replication, EMBO J. 30, 4033-4046.

23. Piazza, A., Adrian, M., Samazan, F., Heddi, B., Hamon, F., Serero, A., Lopes, J., Teulade-Fichou, M. P., Phan, A. T., and Nicolas, A. (2015) Short loop length and high thermal stability determine genomic instability induced by G-quadruplex-forming minisatellites, EMBO J. 34, 1718-1734.

24. Pennarun, G., Granotier, C., Hoffschir, F., Mandine, E., Biard, D., Gauthier, L. R., and Boussin, F. D. (2008) Role of ATM in the telomere response to the G-quadruplex ligand 360A, Nucleic Acids Res. 36, 1741-1754.

25. Pennarun, G., Granotier, C., Gauthier, L. R., Gomez, D., Hoffschir, F., Mandine, E., Riou, J. F., Mergny, J. L., Mailliet, P., and Boussin, F. D. (2005) Apoptosis related to telomere instability and cell cycle alterations in human glioma cells treated by new highly selective G-quadruplex ligands, Oncogene 24, 2917-2928.

26. Rodriguez, R., Müller, S., Yeoman, J. A., Trentesaux, C., Riou, J. F., and Balasubramanian, S. (2008) A novel small molecule that alters shelterin integrity and triggers a DNA-damage response at telomeres, J. Am. Chem. Soc. 130, 15758-15759.

27. Salvati, E., Leonetti, C., Rizzo, A., Scarsella, M., Mottolese, M., Galati, R., Sperduti, I., Stevens, M. F., D'Incalci, M., Blasco, M., Chiorino, G., Bauwens, S., Horard, B., Gilson, E., Stoppacciaro, A., Zupi, G., and Biroccio, A. (2007) Telomere damage induced by the G-quadruplex ligand RHPS4 has an antitumor effect, J. Clin. Invest. 117, 3236-3247.

28. Balasubramanian, S., Hurley, L. H., and Neidle, S. (2011) Targeting G-quadruplexes in gene promoters: a novel anticancer strategy?, Nat. Rev. Drug Discov. 10, 261-275.

29. Hurley, L. H., Von Hoff, D. D., Siddiqui-Jain, A., and Yang, D. (2006) Drug targeting of the c-MYC promoter to repress gene expression via a G-quadruplex silencer element, Semin. Oncol. 33, 498512.

30. Boddupally, P. V., Hahn, S., Beman, C., De, B., Brooks, T. A., Gokhale, V., and Hurley, L. H. (2012) Anticancer activity and cellular repression of c-MYC by the G-quadruplex-stabilizing 11piperazinylquindoline is not dependent on direct targeting of the G-quadruplex in the c-MYC promoter, J. Med. Chem. 55, 6076-6086.

31. Neidle, S. (2010) Human telomeric G-quadruplex: the current status of telomeric G-quadruplexes as therapeutic targets in human cancer, FEBS J. 277, 1118-1125.

32. Duan, W., Rangan, A., Vankayalapati, H., Kim, M. Y., Zeng, Q., Sun, D., Han, H., Fedoroff, O. Y., Nishioka, D., Rha, S. Y., Izbicka, E., Von Hoff, D. D., and Hurley, L. H. (2001) Design and synthesis of fluoroquinophenoxazines that interact with human telomeric $\mathrm{G}$-quadruplexes and their biological effects, Mol. Cancer Ther. 1, 103-120.

33. Lavrado, J., Brito, H., Borralho, P. M., Ohnmacht, S. A., Kim, N. S., Leitao, C., Pisco, S., Gunaratnam, M., Rodrigues, C. M., Moreira, R., Neidle, S., and Paulo, A. (2015) KRAS oncogene repression in colon cancer cell lines by G-quadruplex binding indolo[3,2-c]quinolines, Sci. Rep. 5, 9696.

34. Leonetti, C., Scarsella, M., Riggio, G., Rizzo, A., Salvati, E., D'Incalci, M., Staszewsky, L., Frapolli, R., Stevens, M. F., Stoppacciaro, A., Mottolese, M., Antoniani, B., Gilson, E., Zupi, G., and Biroccio, A. (2008) G-quadruplex ligand RHPS4 potentiates the antitumor activity of camptothecins in preclinical models of solid tumors, Clin. Cancer Res. 14, 7284-7291.

35. Berardinelli, F., Sgura, A., Di Masi, A., Leone, S., Cirrone, G. A., Romano, F., Tanzarella, C., and Antoccia, A. (2014) Radiation-induced telomere length variations in normal and in Nijmegen Breakage Syndrome cells, Int. J. Radiat. Biol. 90, 45-52.

36. Merle, P., Evrard, B., Petitjean, A., Lehn, J. M., Teulade-Fichou, M. P., Chautard, E., De Cian, A., Guittat, L., Tran, P. L., Mergny, J. L., Verrelle, P., and Tchirkov, A. (2011) Telomere targeting with a new G4 ligand enhances radiation-induced killing of human glioblastoma cells, Mol. Cancer Ther. 10, 1784-1795.

37. Merle, P., Gueugneau, M., Teulade-Fichou, M. P., Müller-Barthélémy, M., Amiard, S., Chautard, E., Guetta, C., Dedieu, V., Communal, Y., Mergny, J. L., Gallego, M., White, C., Verrelle, P., and 
Tchirkov, A. (2015) Highly efficient radiosensitization of human glioblastoma and lung cancer cells by a G-quadruplex DNA binding compound, Sci. Rep. 5, 16255.

38. Di Antonio, M., McLuckie, K. I., and Balasubramanian, S. (2014) Reprogramming the mechanism of action of chlorambucil by coupling to a G-quadruplex ligand, J. Am. Chem. Soc. 136, 5860-5863.

39. Verga, D., Hamon, F., Poyer, F., Bombard, S., and Teulade-Fichou, M. P. (2014) Photo-cross-linking probes for trapping G-quadruplex DNA, Angew. Chem. Int. Ed. 53, 994-998.

40. Wang, D., and Lippard, S. J. (2005) Cellular processing of platinum anticancer drugs, Nat. Rev. Drug Discov. 4, 307-320.

41. Rao, L., Dworkin, J. D., Nell, W. E., and Bierbach, U. (2011) Interactions of a Platinum-Modified Perylene Derivative with the Human Telomeric G-Quadruplex, J. Phys. Chem. B 115, 13701-13712.

42. Bombard, S., Gariboldi, M. B., Monti, E., Gabano, E., Gaviglio, L., Ravera, M., and Osella, D. (2010) Biological activity of enantiomeric complexes [PtCl(2)L (2)] (L (2) is aromatic bisphosphanes and aromatic diamines), J. Biol. Inorg. Chem. 15, 841-850.

43. Ourliac-Garnier, I., Charif, R., and Bombard, S. (2009) Telomeres-Targets for platinum anticancer drugs, In Metal Complexes-DNA Interactions (Hadjiliadis, N., and Sletten, E., Eds.), pp 209-234, Wiley-Blackwell.

44. Bertrand, H., Bombard, S., Monchaud, D., Talbot, E., Guedin, A., Mergny, J. L., Grunert, R., Bednarski, P. J., and Teulade-Fichou, M. P. (2009) Exclusive platination of loop adenines in the human telomeric G-quadruplex, Org. Biomol. Chem. 7, 2864-2871.

45. Rao, L., and Bierbach, U. (2007) Kinetically favored platination of adenine in the g-rich human telomeric repeat, J. Am. Chem. Soc. 129, 15764-15765.

46. Bertrand H, Bombard S, Monchaud D, and Teulade-Fichou, M. P. (2007) A Platinum-Quinacridine Hybrid as G-Quadruplex Ligand, J. Biol. Inorg. Chem. 12, 1003-1014.

47. Ourliac-Garnier, I., Elizondo-Riojas, M. A., Redon, S., Farrell, N. P., and Bombard, S. (2005) Crosslinks of quadruplex structures from human telomeric DNA by dinuclear platinum complexes show the flexibility of both structures, Biochemistry 44, 10620-10634.

48. Mailliet, P., Marinetti, A., and Skander, M. (2009) Dérivés platine-carbènes N-heterocyclique, leur préparation et leur application thérapeutique, In Sanofi Aventis-CNRS, Patent WO2009/118475, France.

49. Skander, M., Retailleau, P., Bourrie, B., Schio, L., Mailliet, P., and Marinetti, A. (2010) N-heterocyclic carbene-amine $\mathrm{Pt}(\mathrm{II})$ complexes, a new chemical space for the development of platinum-based anticancer drugs, J. Med. Chem. 53, 2146-2154.

50. Chtchigrovsky, M., Eloy, L., Jullien, H., Saker, L., Segal-Bendirdjian, E., Poupon, J., Bombard, S., Cresteil, T., Retailleau, P., and Marinetti, A. (2013) Antitumor trans-N-heterocyclic carbene-amine$\mathrm{Pt}(\mathrm{II})$ complexes: synthesis of dinuclear species and exploratory investigations of DNA binding and cytotoxicity mechanisms, J. Med. Chem. 56, 2074-2086.

51. Markó, I. E., Stérin, S., Buisine, O., Mignani, G., Branlard, P., Tinant, B., and Declercq, J.-P. (2002) Selective and efficient platinum ${ }^{(0)}$-carbene complexes as hydrosilylation catalysts, Science $298,204-$ 206.

52. Berthon-Gelloz, G., Buisine, O., Brière, J.-F., Michaud, G., Stérin, S., Mignani, G., Tinant, B., Declercq, J.-P., Chapon, D., and Markó, I. E. (2005) Synthetic and structural studies of NHC-Pt(dvtms) complexes and their application as alkene hydrosilylation catalysts (NHC $=N$-heterocyclic carbene, dvtms = divinyltetramethylsiloxane), J. Organomet. Chem. 690, 6156-6168.

53. Hittinger, A., Caulfield, T., Mailliet, P., Bouchard, H., Mandine, E., Mergny, J.-L., Guittat, L., Riou, J.F., Gomez, D., and Belmokhtar, C. (2007) Chemical derivatives as antitelomerase agents which bind specifically to the G-quadruplex DNA structures and their application as a specific anticancer agent, In US2007/232572 A1, Patent US2007/232572.

54. Yang, P., De Cian, A., Teulade-Fichou, M. P., Mergny, J. L., and Monchaud, D. (2009) Engineering bisquinolinium/thiazole orange conjugates for fluorescent sensing of G-quadruplex DNA, Angew. Chem. Int. Ed. 48, 2188-2191.

55. Dorazco-Gonzalez, A., Alamo, M. F., Godoy-Alcantar, C., Hopfl, H., and Yatsimirsky, A. K. (2014) Fluorescent anion sensing by bisquinolinium pyridine-2,6-dicarboxamide receptors in water, RSC Adv. 4, 455-466. 
56. Rendina, L. M., and Puddephatt, R. J. (1997) Oxidative addition reactions of organoplatinum (II) complexes with nitrogen-donor ligands, Chem. Rev. 97, 1735-1754.

57. Moustafa, M. E., McCready, M. S., and Puddephatt, R. J. (2012) Switching by photochemical transcis isomerization of azobenzene substituents in organoplatinum complexes, Organometallics 31, 6262-6269.

58. Safa, M., and Puddephatt, R. J. (2014) Chelating imidazole ligands promote oxidative addition in dimethylplatinum (II) complexes, J. Organomet. Chem. 761, 42-50.

59. Largy, E., Hamon, F., and Teulade-Fichou, M. P. (2011) Development of a high-throughput G4-FID assay for screening and evaluation of small molecules binding quadruplex nucleic acid structures, Anal. Bioanal. Chem. 400, 3419-3427.

60. Amrane, S., Adrian, M., Heddi, B., Serero, A., Nicolas, A., Mergny, J. L., and Phan, A. T. (2012) Formation of pearl-necklace monomorphic G-quadruplexes in the human CEB25 minisatellite, $J$. Am. Chem. Soc. 134, 5807-5816.

61. Renaud de la Faverie, A., Hamon, F., Di Primo, C., Largy, E., Dausse, E., Delauriere, L., LandrasGuetta, C., Toulme, J. J., Teulade-Fichou, M. P., and Mergny, J. L. (2011) Nucleic acids targeted to drugs: SELEX against a quadruplex ligand, Biochimie 93, 1357-1367.

62. Neidle, S. (2009) The structures of quadruplex nucleic acids and their drug complexes, Curr. Opin. Struct. Biol. 19, 239-250.

63. Cummings, S. D. (2009) Platinum complexes of terpyridine: Interaction and reactivity with biomolecules, Coord. Chem. Rev. 253 1495-1516.

64. Musetti, C., Nazarov, A. A., Farrell, N. P., and Sissi, C. (2011) DNA reactivity profile of trans-platinum planar amine derivatives, ChemMedChem 6, 1283-1290.

65. Jung, Y., and Lippard, S. J. (2007) Direct cellular responses to platinum-induced DNA damage, Chem. Rev. 107, 1387-1407.

66. Coluccia, M., and Natile, G. (2007) Trans-Platinum Complexes in Cancer Therapy, Anti-Cancer Agents Med. Chem. 7, 111-123.

67. Largy, E., Hamon, F., Rosu, F., Gabelica, V., De Pauw, E., Guedin, A., Mergny, J. L., and TeuladeFichou, M. P. (2011) Tridentate N-donor palladium(II) complexes as efficient coordinating quadruplex DNA binders, Chem. Eur. J. 17, 13274-13283.

68. Ourliac Garnier, I., and Bombard, S. (2007) GG sequence of DNA and the human telomeric sequence react with cis-diammine-diaquaplatinum at comparable rates, J. Inorg. Biochem. 101, 514-524.

69. Bartel, C., Bytzek, A. K., Scaffidi-Domianello, Y. Y., Grabmann, G., Jakupec, M. A., Hartinger, C. G., Galanski, M., and Keppler, B. K. (2012) Cellular accumulation and DNA interaction studies of cytotoxic trans-platinum anticancer compounds, J. Biol. Inorg. Chem. 17, 465-474.

70. Kalinowska-Lis, U., Ochocki, J., and Matlawska-Wasowska, K. (2008) Trans geometry in platinum antitumor complexes, Coord. Chem. Rev. 252, 1328-1345.

71. Natile, G., and Coluccia, M. (2001) Current status of trans-platinum compounds in cancer therapy, Coord. Chem. Rev. 216, 383-410.

72. Gauthier, L. R., Granotier, C., Hoffschir, F., Etienne, O., Ayouaz, A., Desmaze, C., Mailliet, P., Biard, D. S., and Boussin, F. D. (2012) Rad51 and DNA-PKcs are involved in the generation of specific telomere aberrations induced by the quadruplex ligand 360A that impair mitotic cell progression and lead to cell death, Cell Mol. Life Sci. 69, 629-640.

73. Palm, W., and de Lange, T. (2008) How shelterin protects mammalian telomeres, Annu. Rev. Genet. 42, 301-334.

74. Rizzo, A., Salvati, E., Porru, M., D'Angelo, C., Stevens, M. F., D'Incalci, M., Leonetti, C., Gilson, E., Zupi, G., and Biroccio, A. (2009) Stabilization of quadruplex DNA perturbs telomere replication leading to the activation of an ATR-dependent ATM signaling pathway, Nucleic Acids Res. 37, 53535364.

75. Simonet, T., Zaragosi, L. E., Philippe, C., Lebrigand, K., Schouteden, C., Augereau, A., Bauwens, S., Ye, J., Santagostino, M., Giulotto, E., Magdinier, F., Horard, B., Barbry, P., Waldmann, R., and Gilson, E. (2011) The human TTAGGG repeat factors 1 and 2 bind to a subset of interstitial telomeric sequences and satellite repeats, Cell Res. 21, 1028-1038. 
76. Ourliac-Garnier, I., Poulet, A., Charif, R., Amiard, S., Magdinier, F., Rezaï, K., Gilson, E., Giraud-Panis, M., and Bombard, S. (2010) Platination of telomeric DNA by cisplatin disrupts recognition by TRF2 and TRF1, J. Biol. Inorg. Chem 15, 641-654.

77. Luke, B., and Lingner, J. (2009) TERRA: telomeric repeat-containing RNA, EMBO J. 28, 2503-2510.

78. Porro, A., Feuerhahn, S., Delafontaine, J., Riethman, H., Rougemont, J., and Lingner, J. (2014)

Functional characterization of the TERRA transcriptome at damaged telomeres, Nat. Commun. 5, 5379.

79. Huppert, J. L., and Balasubramanian, S. (2005) Prevalence of quadruplexes in the human genome, Nucleic Acids Res. 33, 2908-2916.

80. Huppert, J. L., and Balasubramanian, S. (2007) G-quadruplexes in promoters throughout the human genome, Nucleic Acids Res. 35, 406-413.

81. Lam, E. Y., Beraldi, D., Tannahill, D., and Balasubramanian, S. (2013) G-quadruplex structures are stable and detectable in human genomic DNA, Nat. Commun. 4, 1796.

82. Chambers, V. S., Marsico, G., Boutell, J. M., Di Antonio, M., Smith, G. P., and Balasubramanian, S. (2015) High-throughput sequencing of DNA G-quadruplex structures in the human genome, Nat. Biotechnol.

83. Fumagalli, M., Rossiello, F., Clerici, M., Barozzi, S., Cittaro, D., Kaplunov, J. M., Bucci, G., Dobreva, M., Matti, V., Beausejour, C. M., Herbig, U., Longhese, M. P., and d'Adda di Fagagna, F. (2012) Telomeric DNA damage is irreparable and causes persistent DNA-damage-response activation, Nat. Cell. Biol. 14, 355-365.

84. Phan, A. T. (2010) Human telomeric G-quadruplex: structures of DNA and RNA sequences, FEBS J. 277, 1107-1117.

85. Kuryavyi, V., Phan, A. T., and Patel, D. J. (2010) Solution structures of all parallel-stranded monomeric and dimeric G-quadruplex scaffolds of the human c-kit2 promoter, Nucleic Acids Res. 38, 6757-6773.

86. Phan, A. T., Modi, Y. S., and Patel, D. J. (2004) Propeller-type parallel-stranded G-quadruplexes in the human c-myc promoter, J. Am. Chem. Soc. 126, 8710-8716.

87. Porro, A., Feuerhahn, S., Reichenbach, P., and Lingner, J. (2010) Molecular dissection of telomeric repeat-containing RNA biogenesis unveils the presence of distinct and multiple regulatory pathways, Mol. Cell Biol. 30, 4808-4817.

88. Sampl, S., Pramhas, S., Stern, C., Preusser, M., Marosi, C., and Holzmann, K. (2012) Expression of telomeres in astrocytoma WHO grade 2 to 4: TERRA level correlates with telomere length, telomerase activity, and advanced clinical grade, Transl. Oncol. 5, 56-65.

89. Cawthon, R. M. (2002) Telomere measurement by quantitative PCR, Nucleic Acids Res 30, e47.

90. Gil, M. E., and Coetzer, T. L. (2004) Real-time quantitative PCR of telomere length, Mol. Biotechnol. $27,169-172$. 